\title{
Comparative study on tertiary contacts and folding of RNase P RNAs from a psychrophilic, a mesophilic/ radiation-resistant, and a thermophilic bacterium
}

\author{
MICHAL MARSZALKOWSKI, ${ }^{1,3}$ ANDREAS WERNER, ${ }^{2,4}$ RALPH FELTENS, ${ }^{1,5}{ }^{2}$ DOMINIK HELMECKE, ${ }^{1}$ \\ MARKUS GÖßRINGER, ${ }^{1}$ ERIC WESTHOF, ${ }^{2}$ and ROLAND K. HARTMANN ${ }^{1}$ \\ ${ }^{1}$ Philipps-Universität Marburg, Institut für Pharmazeutische Chemie, D-35037 Marburg, Germany \\ 2Université de Strasbourg, Institut de biologie moléculaire et cellulaire du CNRS, Architecture et Réactivité de l'ARN, F-67084 Strasbourg, France
}

\begin{abstract}
In most bacterial type A RNase P RNAs (P RNAs), two major loop-helix tertiary contacts (L8-P4 and L18-P8) help to orient the two independently folding $S$ - and C-domains for concerted recognition of precursor tRNA substrates. Here, we analyze the effects of mutations in these tertiary contacts in P RNAs from three different species: (i) the psychrophilic bacterium Pseudoalteromonas translucida (Ptr), (ii) the mesophilic radiation-resistant bacterium Deinococcus radiodurans (Dra), and (iii) the thermophilic bacterium Thermus thermophilus (Tth). We show by UV melting experiments that simultaneous disruption of these two interdomain contacts has a stabilizing effect on all three P RNAs. This can be inferred from reduced RNA unfolding at lower temperatures and a more concerted unfolding at higher temperatures. Thus, when the two domains tightly interact via the tertiary contacts, one domain facilitates structural transitions in the other. P RNA mutants with disrupted interdomain contacts showed severe kinetic defects that were most pronounced upon simultaneous disruption of the L8-P4 and L18-P8 contacts. At $37^{\circ} \mathrm{C}$, the mildest effects were observed for the thermostable Tth RNA. A third interdomain contact, L9-P1, makes only a minor contribution to P RNA tertiary folding. Furthermore, D. radiodurans RNase P RNA forms an additional pseudoknot structure between the P9 and P12 of its S-domain. This interaction was found to be particularly crucial for RNase P holoenzyme activity at near-physiological $\mathrm{Mg}^{2+}$ concentrations ( $\left.2 \mathrm{mM}\right)$. We further analyzed an exceptionally stable folding trap of the G,C-rich Tth P RNA.
\end{abstract}

Keywords: interdomain contacts; UV melting profiles; enzyme kinetics; folding; folding trap; thermostability

\section{INTRODUCTION}

Transfer RNAs (tRNAs) are essential adaptor molecules of cellular protein synthesis machineries. They are synthesized as nonfunctional precursor transcripts (pre-tRNAs) with flanking sequences at their $5^{\prime}$ - and $3^{\prime}$-ends. Ribonuclease $\mathrm{P}$ (RNase $\mathrm{P}$ ) is an essential enzyme that catalyzes the 5'-end maturation of pre-tRNAs (Guerrier-Takada et al. 1983; Waugh and Pace 1990; Gößringer et al. 2006; Hartmann et al. 2009; Klemm et al. 2016). In the majority of Bacteria, RNase $P$ consists of a catalytically active RNA subunit (P RNA, 340 to $400 \mathrm{nt}$ ) and a small protein subunit (P

\footnotetext{
${ }^{3}$ Present address: ul. Jabłoniowa 22/12, 80-175 Gdańsk, Polska

${ }^{4}$ Present address: European Patent Office, Bob-van-BenthemPlatz 1, 80298 Munich, Germany

${ }^{5}$ Present address: Berufsschulzentrum 1 der Stadt Leipzig, D04289 Leipzig, Germany

Corresponding author: roland.hartmann@staff.uni-marburg.de

Article is online at http://www.rnajournal.org/cgi/doi/10.1261/rna. 078735.121 . Freely available online through the RNA Open Access option.
}

protein, $\sim 13 \mathrm{kDa}$ ) that interacts with nucleotides in the pretRNA 5'-leader (Hartmann et al. 2009; Klemm et al. 2016).

Bacterial P RNA is a highly structured molecule, with approximately two-thirds of its nucleotides participating in base-pairing interactions. The basic RNA secondary structure, including structural variations, and major tertiary interactions were inferred from phylogenetic/comparative sequence analyses (Brown et al. 1996; Massire et al. 1997, 1998). Deletion studies revealed that only a subset of helices is strictly essential for catalytic function. These helices form the core structure of all bacterial P RNAs, while several peripheral helices that are attached to the conserved core structure display a variable occurrence and can be individually deleted with only moderate effects on catalytic function (Waugh et al. 1989; Darr et al. 1992;

(C) 2021 Marszalkowski et al. This article, published in RNA, is available under a Creative Commons License (Attribution-NonCommercial 4.0 International), as described at http://creativecommons.org/licenses/ by-nc/4.0/. 
Haas et al. 1994; Schlegl et al. 1994; Siegel et al. 1996). Based on the different peripheral structural elements, bacterial P RNAs can be classified into two major architectures termed type A (ancestral, e.g., Escherichia coli) and type B (Bacillus-like) (Haas et al. 1996; Haas and Brown 1998; Brown 1999).

RNase P RNA is formed from two independently folding units (Loria and Pan 1996), the specificity (S-) domain and the catalytic (C-) domain. In bacterial P RNAs of type A architecture, the two functional domains are oriented toward each other with the help of two to three interdomain loophelix contacts (L18-P8, L8-P4, L9-P1; Fig. 1A-C). Type A RNAs adopt a rather stretched, slightly concave or open



FIGURE 1. Secondary structure presentation of $(A) P$. translucida (strain TAC125), (B) D. radiodurans (strain $\mathrm{R} 1 \mathrm{dM} 1$ ) and $(C)$ T. thermophilus (strain HB8) P RNAs according to Massire et al. (1998), with the three interdomain tetraloop-helix contacts L18-P8, L8-P4, and L9-P1 indicated by dashed blue lines and the involved structural elements in color. Nucleotide exchanges in L8, L9, and L18 ( $\mathrm{mL} 8, \mathrm{~mL}$, and $\mathrm{mL} 18$ ) that disrupt these tertiary interactions are highlighted in red. In the Dra P RNA, the mP9c and "P9c_restored" mutations are illustrated in the boxes. In the P. translucida P RNA (A), the second bp in P1 is shown in small letters to indicate that the bp was mutated from $A: U$ to $G: C$ (for details, see text). Numbering in $C$ is according to Schlegl et al. (1994); numberings in $A$ and $B$ are based on the $r n p B$ genes annotated in the P. translucida strain TAC125 chromosome I (GenBank CR954246.1) and the D. radiodurans strain R1 dM1 chromosome I (GenBank CP031500.1), respectively. umbrella-like overall shape, formed by two layers of helices lying on top of each other. The bound tRNA occupies the position of the umbrella shaft (Reiter et al. 2010; illustrated in Supplemental Fig. S1). The smaller helical layer consists of the peripheral helices P18 and P13/14 that stabilize the stretched $\mathrm{P}$ RNA conformation via their tertiary contacts. The P8/P9 stack is at the interface between the C-domain and the more distal parts of the S-domain (P13/P14 and P7/P10/P11/P12). Structurally, the L8-P4 and L1-P9 contacts support the side-by-side arrangement of the P1/P4/ P5 and P8/P9 helical stacks (for review, see Gößringer et al. 2021). Among those interdomain contacts, L8-P4 is common and ubiquitous to bacterial P RNAs of type A and B (Massire et al. 1997, 1998). In Archaea, the RNA subunit forms a holoenzyme with five protein subunits (Jarrous and Gopalan 2010), and folding of the P RNA into its active three-dimensional conformation is more dependent on RNA-protein and protein-protein interactions. This led, for example, to the loss of the L8-P4 interdomain contact in archaeal P RNAs of type M present in Methanococcales. Also, the L9-P1 contact, although basically able to form in type M RNAs (Lai et al. 2017), appears to require structural support from interaction of P1/P9 with protein subunits Rpp21/Rpp29 (Wan et al. 2019).

The long-range interactions in P RNAs of type A, originally inferred from phylogenetic covariation analyses, were later confirmed in the P RNA and holoenzyme crystal structures of Thermotoga maritima RNase P (Torres-Larios et al. 2005; Reiter et al. 2010). Yet, our knowledge on the individual contributions of these long-range interactions to P RNA function and how they mutually affect folding of the two domains is still incomplete. To address these questions, we have disrupted the L9-P1, L8-P4, and/or L18P8 interaction by mutation in three model type $A P$ RNAs: the thermostable, G,C-rich P RNA of the thermophile Thermus thermophilus (Tth), the one from the psychrophilic bacterium Pseudoalteromonas translucida (Ptr) and the P RNA of Deinococcus radiodurans (Dra), a mesophilic, radiation-resistant bacterium phylogenetically related to $T$. thermophilus. These three type A P RNAs were chosen because of the following outstanding features. Tth P RNA is among the most thermostable P RNAs known. Thermostability of its S-domain was inferred to be achieved by conversion of strategic base pairs to G-C, by decreasing surface accessibility of the native fold and by increasing the amount of structure formation in the native folding transition (Baird et al. 2006). In addition, its two domains form a reinforced L9-P1 contact that contributes to thermostability (Marszalkowski et al. 2008). Dra P RNA deviates substantially form canonical type A structures owing to a P9 stem extension, in which L9 has become an internal loop and where the P9 extension forms a pseudoknot (P9C) with L12, likely to reinforce the S-domain structure (Fig. 1B). The P RNA of the psychrophilic bacterium $P$. translucida TAC125 (originally named 
Pseudoalteromonas haloplanktis TAC125; Medigue et al. 2005) may provide hints as to whether adaptation of its host to growth at low temperatures has left traces in the evolution of its $P$ RNA structure. $P$. translucida grows at temperatures between $4{ }^{\circ} \mathrm{C}$ and $30^{\circ} \mathrm{C}$ (Corsaro et al. 2004), D. radiodurans has an optimal growth temperature of $\sim 30^{\circ} \mathrm{C}$ (Airo et al. 2004; Appukuttan et al. 2006) and T. thermophilus grows between $47^{\circ} \mathrm{C}$ and $85^{\circ} \mathrm{C}$, optimally thriving at $65^{\circ} \mathrm{C}$ to $72^{\circ} \mathrm{C}$ (Oshima and Imahori 1974).

To shed light on the role of individual interdomain contacts on P RNA folding and function, we analyzed mutated $P$ RNAs with disrupted interdomain contacts using (i) UV melting to study the effect of the tertiary contacts on RNA folding, (ii) pre-tRNA processing to determine their role for activity, and (iii) complementation of a conditionally lethal E. coli (Eco) P RNA ( $m p B)$ mutant strain to assess their in vivo function in a mesophilic host. We further investigated an exceptionally severe trap in the folding pathway of the thermostable Tth P RNA. The RNA was shown to be

B

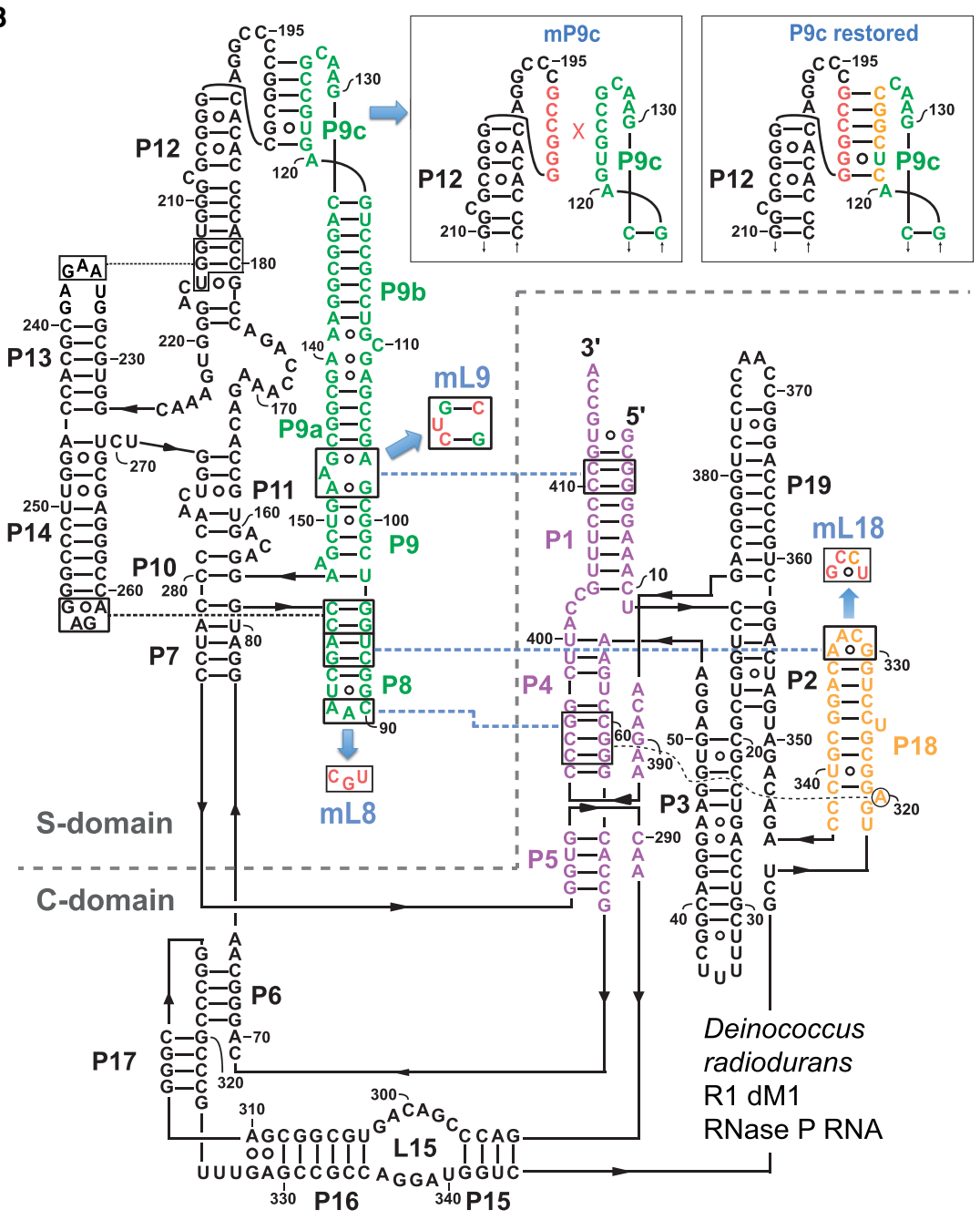

unable to function in the mesophilic Eco host and strictly requires a $\mathrm{Mg}^{2+}$-dependent preincubation step at $\sim 55^{\circ} \mathrm{C}$ for folding in vitro into its active structure (Marszalkowski et al. 2008). We thus analyzed this folding trap in more depth via folding kinetics and RNA structure probing.

\section{RESULTS}

\section{Mutant construction}

The L18-P8 tertiary contact was disrupted in the three P RNAs (Ptr, Dra and Tth) by mutating the GNRA tetraloop of L18 to an UNCG loop (Fig. 1). Both loops maintain an interaction between positions 1 and 4 of the tetraloop (Pomeranz Krummel and Altman 1999) to preserve the hairpinstabilizing ability. The L8-P4 interdomain contact was disrupted by changing the $L 8$ sequence from $5^{\prime}$-AAC to $5^{\prime}$ CGU in the three RNAs (Fig. 1). The UNCG tetraloop mutation was further introduced into L9 of Ptr and Tth (Marszalkowski et al. 2008) P RNAs to disrupt the L9-P1 contact (Fig. 1A,C). In Dra $P R N A$, the contact between the internal L9 loop and P1 was abolished by changing the bulged $A$ on the $3^{\prime}$-side of $L 9$ to $U$ and by converting the two flanking $\mathrm{G} \bullet A$ pairs into $\mathrm{G}-\mathrm{C}$ pairs (Fig. 1B). For Dra P RNA, we also disrupted the idiosyncratic pseudoknot P9C formed between the apical regions of P12 and the extended P9 element by mutation of the involved L12 nucleotides (Fig. 1B). Disruption of this intra-S-domain interaction enabled us to assess to which extent this interaction contributes to RNA folding and function.

\section{UV melting studies}

Folding of $P$ RNA proceeds from an unfolded (U) state, traverses a counterion-dependent intermediate state (I) to reach the final $\mathrm{Mg}^{2+}$-dependent native (N) state. In the I state, the majority of base-pairing and stacking interactions have formed. The transition of the $P$ RNA structure from the $I$ to the $U$ state (and vice versa) can be measured by UV spectroscopy. However, near-UV circular dichroism (CD) is required to study the second transition (I to $\mathrm{N}$ ) that mainly changes the molecular compactness and helicity parameters (Pan and Sosnick 1997). $\mathrm{Mg}^{2+}$ ions not only contribute to charge

Fig. 1. Continued. 
shielding, but also occupy specific $\mathrm{Mg}^{2+}$ binding sites. In addition, $\mathrm{Mg}^{2+}$ ions can stabilize kinetic folding traps. As this complicates UV melting profiles, we performed melting experiments in the presence of $100 \mathrm{mM} \mathrm{Na}^{+}$and absence of $\mathrm{Mg}^{2+}$ to confine the effects of counterions to electrostatic shielding. We also noticed that folding in the presence of $\mathrm{Na}^{+}$was always more reproducible than with $\mathrm{Mg}^{2+}$, associated with the additional advantage that the RNA could be subjected to repeated heating and annealing cycles while avoiding the risk of metal ion-induced P RNA degradation at high temperatures.

The first derivative $\mathrm{dA}_{260} / \mathrm{dT}$ curves of the three wildtype (WT) P RNAs (green curves in Fig. 2, profiles on the right) revealed major melting transitions at $\sim 60^{\circ} \mathrm{C}$ for Ptr P RNA, at $\sim 57^{\circ} \mathrm{C}$ and $\sim 74^{\circ} \mathrm{C}$ for Dra P RNA and at $\sim 75^{\circ} \mathrm{C}$ for Tth P RNA (Fig. 2A-C). A substantial contribution

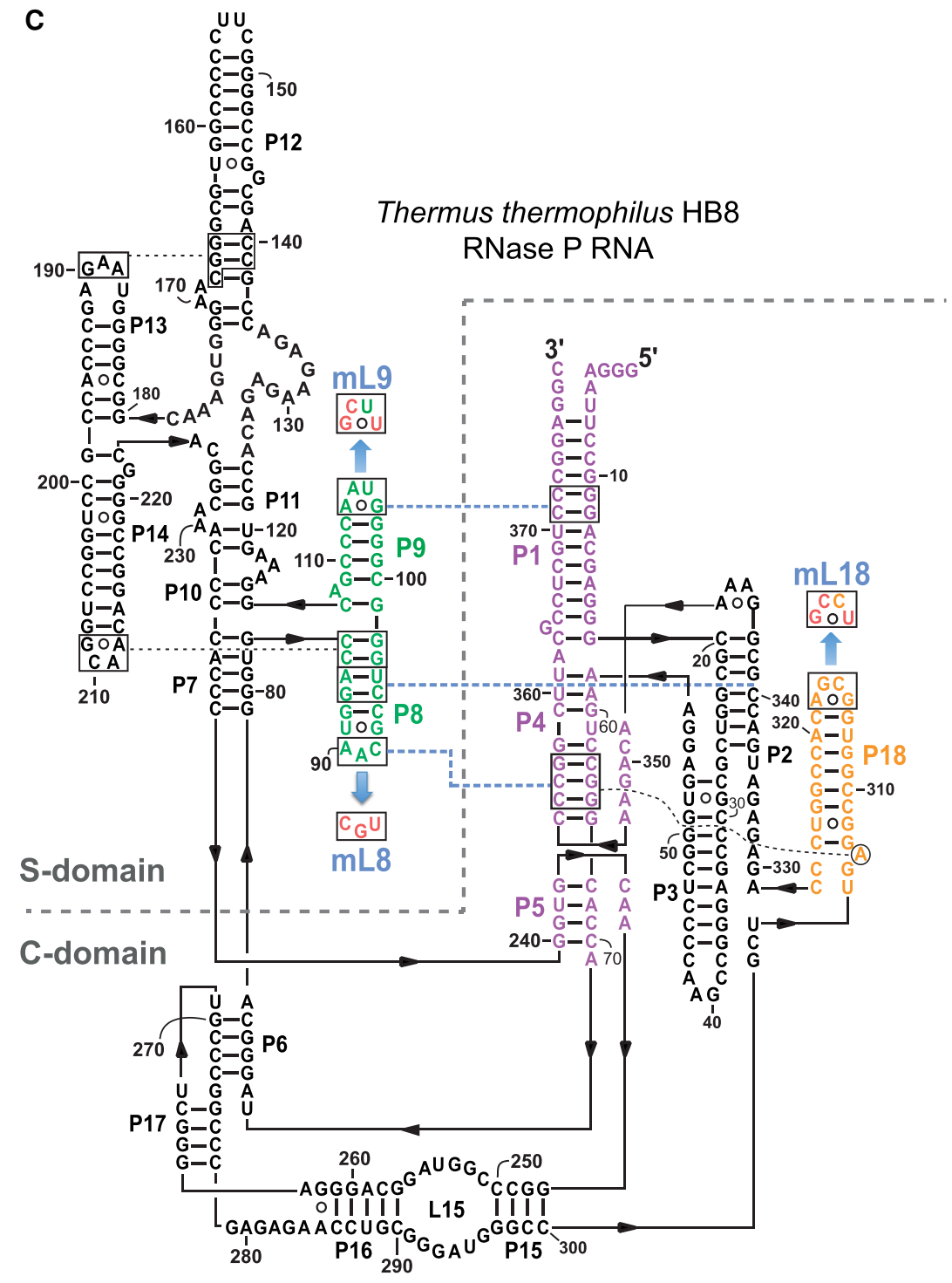

Fig. 1. Continued. to the $74^{\circ} \mathrm{C}$ transition of the Dra P RNA may originate from the long G,C-rich P8/P9/P9a/P9b/P9c stack (Fig. 1B).

The effects of $\mathrm{mL} 8$ and $\mathrm{mL} 18$ mutations (disrupting the L8-P4 and L18-P8 interdomain contacts, respectively) on UV melting profiles depended on the type of $P$ RNA. Both mutations individually had a destabilizing effect on Ptr P RNA, where they caused some partial structures to melt at lower temperatures (approximately between $20^{\circ} \mathrm{C}$ to $40^{\circ} \mathrm{C}$ ) than in the WT P RNA. The melting profile of Tth $P$ RNA was only marginally affected by either the $m L 8$ or mL18 mutation, while both mutations individually stabilized the Dra P RNA, as inferred from the observed reduced unfolding between $50^{\circ} \mathrm{C}$ to $57^{\circ} \mathrm{C}$ (Fig. 2B, profiles on the right). Particularly the $\mathrm{mL} 18$ mutation changed the Dra $\mathrm{P}$ RNA melting profile to a major peak at $\sim 64^{\circ} \mathrm{C}$ in the first derivative curve. However, simultaneous disruption of both interdomain contacts, L18-P8 and L8-P4, stabilized all three P RNAs, in the sense that more structure unfolded concertedly at higher temperatures (Fig. 2, profiles on the right). For Ptr P RNA, this went along with an upshift of the major peak to $\sim 62^{\circ}$ $\mathrm{C}(\mathrm{mL} 8 / \mathrm{L} 18)$ and markedly decreased hyperchromicity at lower temperatures (Fig. 2A). For Dra and Tth $P$ RNA, the double mutation decreased melting of structures in the temperature range of $\sim 40^{\circ} \mathrm{C}$ (Dra) or $\sim 30^{\circ} \mathrm{C}$ (Tth) to almost $60^{\circ} \mathrm{C}$ (Fig. $2 \mathrm{~B}$, C). Overall, the stabilizing effect upon disrupting the L18-P8 and L8P4 interdomain contact was most pronounced for PtrP RNA, the most A, Urich of the three compared RNAs.

Measurements with the isolated Ptr $S$-domain revealed that the major unfolding transition of the WT Ptr P RNA $\left(\sim 59^{\circ} \mathrm{C}\right)$ is split into two peaks at $62^{\circ} \mathrm{C}$ and $72^{\circ} \mathrm{C}$, respectively (Fig. 3 , right panel). Thus, the Ptr S-domain is more stable than the full-length WT P RNA, and its major transition at $62^{\circ} \mathrm{C}$ coincides with that of the fulllength $P$ RNA carrying the $m L 8 / L 18$ double mutation (Fig. 3, right panel). The effects of long-range interactions on the UV melting profile are not confined to interdomain contacts. Disruption of the intra-S-domain L12-L9C pseudoknot in the P9C mutant had a similar effect as the $\mathrm{mL} 18$ mutation in the context of the fulllength Dra P RNA, resulting in a more concerted and upshifted melting 

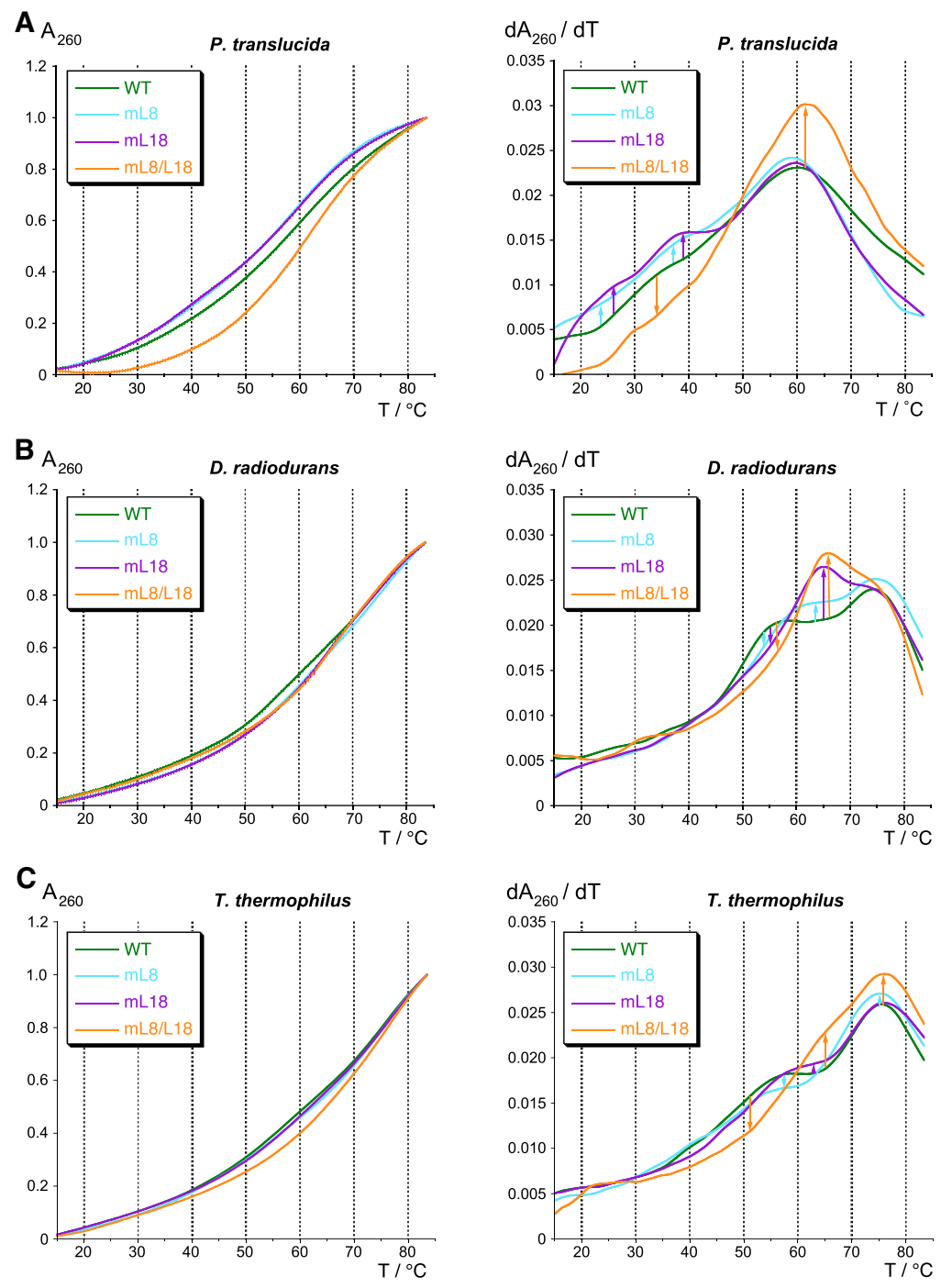

FIGURE 2. UV absorbance (left) and derivative (right) melting profiles for $\operatorname{Ptr}(A), \operatorname{Dra}(B), T$ th $(C)$ P RNAs and mutants thereof, measured in $10 \mathrm{mM}$ sodium cacodylate $\mathrm{pH} 7.0,0.5 \mathrm{mM}$ EDTA, and $100 \mathrm{mM} \mathrm{NaCl}$ (RNA concentration $25 \mathrm{nM}$, averages of three to four curves each). Changes in the melting transitions between wild-type (WT) and corresponding mutant P RNAs are indicated by vertical arrows in the first derivative plots on the right. transition at $62^{\circ} \mathrm{C}$ (Figs. 4, 2B, right panels). Restoring pseudoknot formation by introducing compensatory mutations into the P9C mutant again reduced the prevalence of the transition at $\sim 62^{\circ} \mathrm{C}$ similar to the WT Dra $\mathrm{P}$ RNA (Fig. 4).

\section{A folding trap of $T$. thermophilus RNase P RNA}

In vitro transcripts of $T$. thermophilus $P$ RNA require a preincubation step at temperatures higher than $37^{\circ} \mathrm{C}$ (e.g., at $55^{\circ} \mathrm{C}$ ) for activation (Hartmann and Erdmann 1991; Marszalkowski et al. 2008). This suggested that the native folding transition has an extraordinarily high activation energy barrier so far unprecedented among bacterial $P$ RNAs. Here we analyzed the nature of this temperature-dependent folding transition in more detail. The requirement for a $55^{\circ} \mathrm{C}$ preincubation step was seen at $\mathrm{Mg}^{2+}$ concentrations between 10 to $100 \mathrm{mM} \mathrm{Mg}^{2+}$ (Supplemental Fig. S2A). In contrast, preincubation of Eco P RNA at $55^{\circ} \mathrm{C}$ versus $37^{\circ} \mathrm{C}$ had no or at most a twofold effect, depending on the $\mathrm{Mg}^{2+}$ concentration (Supplemental Fig. S2B). Folding kinetics of Tth $P$ RNA were further investigated at $20 \mathrm{nM} \mathrm{P}$ RNA and $200 \mathrm{nM}$ pre-tRNA in the RNA-alone reaction in the presence of $20 \mathrm{mM} \mathrm{Mg}^{2+}$. Preincubation of T. thermophilus $P$ RNA for $15 \mathrm{~min}$ at $37^{\circ} \mathrm{C}$ instead of $55^{\circ} \mathrm{C}$ resulted in slow substrate turnover and sigmoidal kinetics (Fig. 5, curve a versus b). When the RNA was preincubated for $5 \mathrm{~h}$ at $37^{\circ} \mathrm{C}$ before pre-tRNA addition, the rate of substrate cleavage increased, but still did not reach that obtained after preincubation for 15 min at $55^{\circ} \mathrm{C}$ (Fig. 6, curve c versus b). We also analyzed if the presence of the substrate may assist (or inhibit [Pan and Sosnick 1997]) T. thermophilus P RNA folding into an active conformation. After $P$ RNA preincubation for $15 \mathrm{~min}$ at $37^{\circ} \mathrm{C}$,
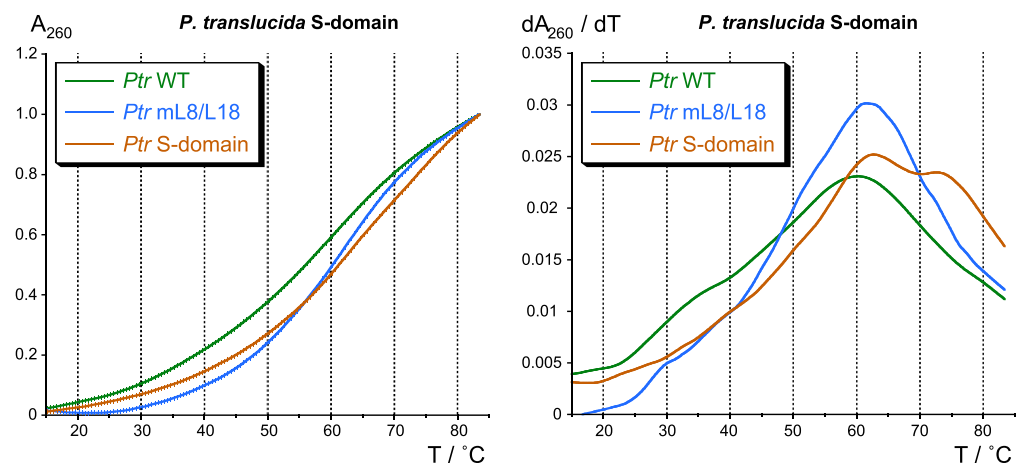

FIGURE 3. UV absorbance (left) and derivative (right) melting profiles of the Ptr P RNA Sdomain (brown) compared to the full-length WT (green) and mL8/L18 mutant Ptr P RNA (blue). Assay conditions were the same as in Figure 2. 
addition of substrate and incubation for $285 \mathrm{~min}$ (without withdrawal of aliquots), fresh pre-tRNA substrate (200 nM) was added and the reaction monitored for another 285 min by withdrawal of aliquots and analysis by $20 \%$ denaturing PAGE. The resulting curve d (Fig. 6) was almost identical to curve c (P RNA preincubated for $5 \mathrm{~h}$ min at $37^{\circ} \mathrm{C}$ ), suggesting that the presence of substrate had little effect on the slow refolding kinetics at $37^{\circ} \mathrm{C}$ and $20 \mathrm{mM}$ $\mathrm{Mg}^{2+}$. The sigmoidal curve " $\mathrm{a}$ " could be fitted to Equation 1 (see below), with $k_{\text {obs }}$ describing the pseudofirst order rate constant for cleavage when essentially all P RNAs are folded (as assumed to be accomplished by preincubation for $15 \mathrm{~min}$ at $55^{\circ} \mathrm{C}$ ), $k_{1}$ the first order rate constant for the slow folding step at $37^{\circ} \mathrm{C}, \mathrm{c}$ the concentration of substrate at any time point, and $c_{0}$ the concentration of substrate at the start of the reaction.

$$
\frac{C}{C_{0}}=\text { Limit } \cdot\left(1-e^{-k_{\text {obs }} \times t} \cdot e^{\frac{k_{o b s} \times e^{-k_{1} \times t_{0}}}{k_{1}}\left(1-e^{-k_{1} \times t}\right)}\right) .
$$

If the rate of cleavage after preincubation at $55^{\circ} \mathrm{C}$ (Fig. 5 , curve $b, k_{o b s}=0.083 \mathrm{~min}^{-1}$ ) is taken as $k_{\text {obs }}$ in Equation 1, a $k_{1}$ value of $0.0016 \mathrm{~min}^{-1}$ for the folding step at $37^{\circ} \mathrm{C}$ is calculated. The overall folding rate of Eco P RNA was determined as $0.54 \mathrm{~min}^{-1}$ (Kent et al. 2000), thus being more than 300-fold faster under similar conditions $(25 \mathrm{mM}$ $\left.\mathrm{Mg}^{2+}, 120 \mathrm{mM} \mathrm{KCl}, \mathrm{pH} 7.0,37^{\circ} \mathrm{C}\right)$. We further measured the rate of folding to the native state via processing activity assay as a function of Tth $P$ RNA preincubation time at $55^{\circ}$ C. The folding rate was determined as $0.13 \mathrm{~min}^{-1}$ (Supplemental Fig. S3A). When P RNA preincubation was performed at $3 \mathrm{M}$ urea, a folding rate enhancement of up to fourfold was observed (Supplemental Fig. S3B), indicating the presence of one or more kinetic traps along the folding pathway (Pan and Sosnick 1997).

A preincubation step at $55^{\circ} \mathrm{C}$ for $\mathrm{P}$ RNA activation was also required in the holoenzyme reaction and efficient $P$ RNA folding depended on the presence of $\mathrm{Mg}^{2+}$ (4.5 mM) during this step (Supplemental Fig. S4A,B). We also analyzed the effect of the preincubation step performed at $37^{\circ} \mathrm{C}$ versus $55^{\circ} \mathrm{C}$ on RNA alone activity for the Tth $\mathrm{mL} 8, \mathrm{~mL} 9, \mathrm{~mL} 18$, and $\mathrm{mL} 8 / \mathrm{L} 18$ mutant P RNAs (Supplemental Fig. S4C). As for the WT Tth P RNA, substantial activity was only obtained upon P RNA preincubation at $55^{\circ} \mathrm{C}$.

\section{Analysis of $T$. thermophilus P RNA folding by RNase T1 probing}

The structure of Tth P RNA was probed by RNase T1 digestion under nondenaturing conditions (Fig. 6). to Figure 2.
RNase T1 cleaves 3' of exposed G residues in flexible regions, and it was already shown for the Tth S-domain that accessibility of $G$ residues largely decreases from the I to the $\mathrm{N}$ state (Baird et al. 2006). For RNase T1 probing, $5^{\prime}$ - or $3^{\prime}$-endlabeled $\mathrm{P}$ RNA was preincubated at $37^{\circ} \mathrm{C}$ or $55^{\circ} \mathrm{C}$, followed by probing at $37^{\circ} \mathrm{C}$. The following regions became protected from RNase T1 cleavage upon preincubation of $5^{\prime}$-endlabeled Tth $\mathrm{P}$ RNA at $55^{\circ} \mathrm{C}$ versus $37^{\circ} \mathrm{C}$ (Fig. 6A, gray vertical lines on the right): P11 ( $3^{\prime}-$ strand), L13 (G192), J11/12, P10, P9, P6-8, P4, J3/4, and the 3 '-side of P3. 3'-endlabeled Tth P RNA provided partially overlapping information, such as protection at G226/7 or signal enhancement (filled dots) at G252/3 upon preincubation at $55^{\circ} \mathrm{C}$; signal intensities were also increased for cleavages in the $3^{\prime}$-part of L15 (G291-3) and in J17/16 (G281/3) (Fig. 6C).

We also analyzed the Tth $\mathrm{mL} 9$ mutant RNA (Fig. 1C) by RNase T1 probing as a function of preincubation temperature. The pattern of protection from RNase T1 hydrolysis upon preincubation at $55^{\circ} \mathrm{C}$ was very similar to that obtained with the WT RNA (Fig. 6B vs. A). The protection of $\mathrm{J} 3 / 4$ upon preincubation at $55^{\circ} \mathrm{C}$ was less pronounced than for the Tth WT P RNA, suggesting that formation of the L9-P1 contact helps burying these residues more tightly in the catalytic core. This minor difference compared with the WT P RNA is consistent with the moderate activity decrease of the $\mathrm{mL9}$ variant in the RNA-alone reaction at high temperatures $\left(55^{\circ} \mathrm{C}\right)$ and at low $\mathrm{Mg}^{2+}$ concentrations in the holoenzyme reaction (Marszalkowski et al. 2008).

In summary, RNase T1 probing revealed substantial structural compaction and surface burial in the S-domain upon preincubation at $55^{\circ} \mathrm{C}$, particularly in P6-9, P11 and J11/12. Similar protections from RNase T1 cleavage were observed with the isolated Tth S-domain upon increasing the $\mathrm{Mg}^{2+}$ concentration from 0.05 to $1.6 \mathrm{mM}$,
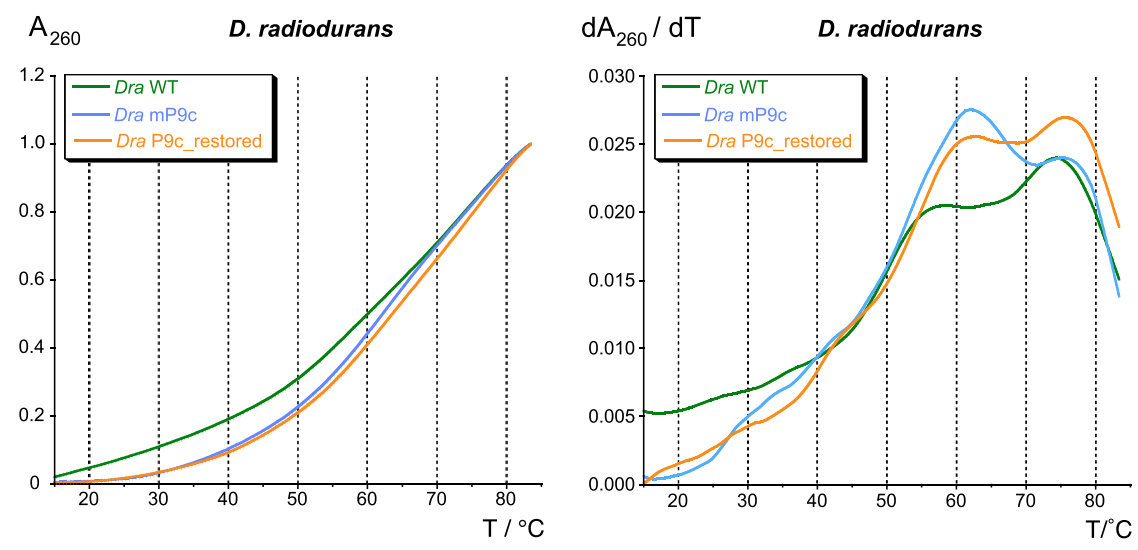

FIGURE 4. UV absorbance (left) and derivative (right) melting profiles of Dra WT P RNA, the $\mathrm{mP9c}$ and the "P9c_restored" variant thereof (see Fig. 1B). For assay conditions, see legend 


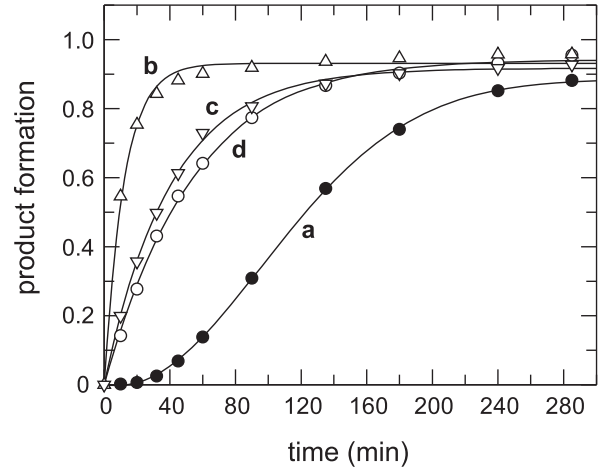

FIGURE 5. Multiple turnover kinetics of pre-tRNA ${ }^{\mathrm{Gly}}(200 \mathrm{nM})$ cleavage by $T$. thermophilus P RNA $(20 \mathrm{nM})$ at $20 \mathrm{mM} \mathrm{Mg}(\mathrm{OAc})_{2}, 100$ $\mathrm{mM} \mathrm{NH}_{4} \mathrm{OAc}, 50 \mathrm{mM} \mathrm{Hepes,} \mathrm{pH} 7.0$, were conducted at $37^{\circ} \mathrm{C}$, but using different preincubation procedures. Curve a: preincubation of $\mathrm{P}$ RNA for $15 \mathrm{~min}$ at $37^{\circ} \mathrm{C}$ before substrate addition. Curve $\mathbf{b}$ : preincubation of $\mathrm{P}$ RNA for $15 \mathrm{~min}$ at $55^{\circ} \mathrm{C}$ before substrate addition. Curve c: preincubation of $\mathrm{P}$ RNA for $5 \mathrm{~h}$ at $37^{\circ} \mathrm{C}$ before substrate addition. Curve d: preincubation of P RNA for $15 \mathrm{~min}$ at $37^{\circ} \mathrm{C}$; after addition of substrate, the reaction was further preincubated for $285 \mathrm{~min}$ (4.75 $h$; without withdrawal of aliquots), whereupon fresh substrate (200 $\mathrm{nM}$ ) was added (final pre-tRNA plus mature tRNA concentration: $400 \mathrm{nM}$ ) and the processing reaction monitored for another period of $285 \mathrm{~min}$.

conditions that were considered to represent the intermediate (I) and native (N) fold of the S-domain, respectively (Baird et al. 2006). The overlap between these previous results and our findings suggests that the folding state of the $\mathrm{S}$-domain within the full-length RNA and before preincubation at $55^{\circ} \mathrm{C}$ resembles the I state of the isolated Sdomain in the study by Baird et al. (2006).

In the C-domain, major compaction occurred in the P6 region (Fig. 6A), suggesting that this structural element forms during the $55^{\circ} \mathrm{C}$ temperature step. Another area of compaction is the $3^{\prime}$-side of P3, J3/4 and helix P4 near its $U$ bulge in the catalytic core. In addition, RNase T1 accessibility in the P15-17 region changed from the I to the $\mathrm{N}$ state (Fig. 6C).

\section{Enzyme kinetic effects upon disruption of L8-P4 and/or L18-P8 interdomain contacts}

The functional role of interdomain contacts in Tth, Ptr and Dra P RNAs was analyzed in single turnover kinetic RNAalone reactions at $37^{\circ} \mathrm{C}$ (Table 1). Disruption of the L8-P4 contact had little effect on Tth P RNA (1.4-fold decrease in $k_{\text {react } /} / K_{\text {m(sto) }}$ relative to the WT RNA) but affected $P$ tr and DraP RNAs more severely (37- and 92-fold decrease in $k_{\text {react- }}$ $K_{m(s t o) ;}$ Table 1). A similar trend was observed for P RNA variants with a disrupted L18-P8 interaction (approximately six-, $37-$, and 28 -fold decrease in $k_{\text {react }} / K_{\text {m(sto) }}$ for $T$ th, Ptrand Dra $P$ RNA, respectively; Table 1). For Tth PRNA, the kinetic defect upon disruption of the L18-P8 interaction was more pronounced in cleavage assays performed at $55^{\circ} \mathrm{C}$ (under other- wise similar conditions; Schlegl et al. 1994) instead of the $37^{\circ} \mathrm{C}$ uniformly applied in the present study.

Simultaneous disruption of the L8-P4 and L18-P8 contacts (variants $\mathrm{mL} 8 / \mathrm{L} 18$ ) impaired activity more severely. Catalytic efficiency $\left[k_{\text {react } /} K_{\mathrm{m}(\mathrm{sto})}\right]$ for the $T$ th $\mathrm{mL} 8 / \mathrm{L} 18$ variant was now $\sim 22$-fold decreased and $\sim 430$-fold and 3000-fold for the Ptr and Dra mL8/L18 variants, respectively (Table 1). Surprisingly, simultaneous disruption of the two interdomain contacts was most detrimental to Dra P RNA function. This may be related to the extension of the P8-P9 stem that is further constrained by the P9C pseudoknot in Dra P RNA. In the absence of the L8-P4 and L18-P8 tertiary contacts, the extended and rigidified P8-P9 stem may be difficult to keep in a productive orientation toward the C-domain or may even lead to steric clashes with the substrate. As a general trend, the thermostable Tth P RNA structure turned out to be more robust than P RNAs from Ptr and Dra, as inferred from the lower sensitivity of the former RNA toward loss of individual interdomain contacts under the conditions tested, in line with previous findings (Marszalkowski et al. 2008). Overall, these findings are consistent with a basic assumption of our model presented in Figure 7, namely that one functional interdomain contact, L8-P4 or L18-P8, can principally maintain domain orientation, while the absence of both contacts severely depletes the fraction of P RNA molecules with a productive domain arrangement.

\section{Analysis of the L9-P1 interaction in Ptr and Dra P RNAs}

We extended our studies to the L9-P1 contact in PtrP RNA. P9 of this RNA harbors a 5'-GCGA-3' tetraloop that is predicted to dock onto the second and third bp in P1. For cloning and expression purposes we changed the second P1 bp of PtrP RNA from A:U to G:C (Fig. 1A). We considered it unlikely that this bp exchange would substantially weaken the L9-P1 interaction (see Supplemental Fig. S5 and its discussion in the Supplement). For the Ptr mL9 mutant RNA, we neither saw a defect in the RNA-alone reaction at $37^{\circ} \mathrm{C}$ (Table 1) nor in the holoenzyme reaction with the heterologous E. colior B. subtilis $P$ protein (Table 3 ). This suggested that the P1-L9 interaction does not make a substantial contribution to the overall stabilization of $P \operatorname{tr} P$ RNA at $37^{\circ} \mathrm{C}$, in line with the corresponding findings for Eco P RNA (Pomeranz Krummel and Altman 1999; Marszalkowski et al. 2008). A possible explanation is that the L9-P1 contact forms only concomitantly (opportunistically) when the L8-P4 and L18-P8 contacts are in place, but in this native context disruption of the L9-P1 contact remains phenotypically silent. To clarify whether the L9-P1 contact can yet form independently, we compared the kinetic performance of Ptr mL8/L18 double and Ptr mL8/L18/L9 triple mutants. In both mutants, we also restored the native $A 2$ : U360 bp in P1 to entirely exclude any effect of the G2: 
A

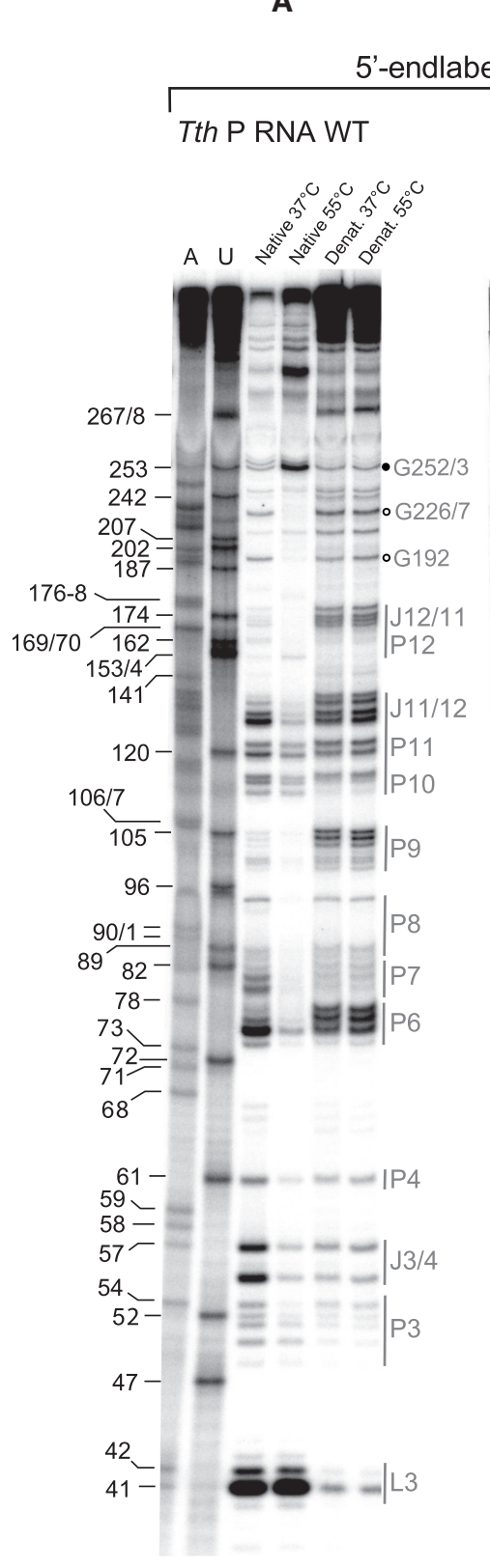

B

Tth P RNA mL9
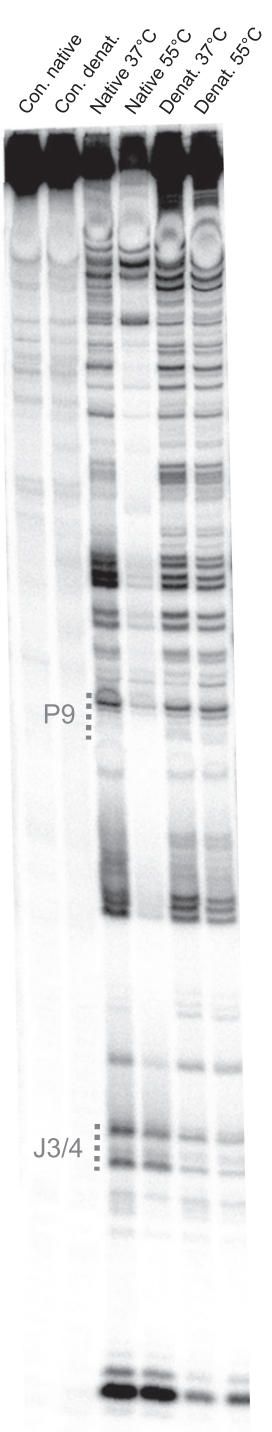

C


(L15)

FIGURE 6. RNase T1 probing of 5'-endlabeled T. thermophilus wild-type (WT) (A) and mL9 mutant P RNA (B), and 3'-endlabeled WT P RNA (C). Lanes A and U: AMP $\alpha$ S- or UMP $\alpha$ S-substituted T. thermophilus WT P RNA used to generate A- and U-specific ladders by iodine hydrolysis; lanes "Native $37^{\circ} \mathrm{C}$ " and "Native $55^{\circ} \mathrm{C}$ ": P RNA preincubated for $10 \mathrm{~min}$ at $37^{\circ} \mathrm{C}$ or $55^{\circ} \mathrm{C}$ in the nondenaturing buffer $\mathrm{B}$ before addition of RNase $\mathrm{T} 1$ and limited hydrolysis for $10 \mathrm{~min}$ at $37^{\circ} \mathrm{C}$; lanes "Denat. $37^{\circ} \mathrm{C}$ " and "Denat. $55^{\circ} \mathrm{C}$ ": P RNA preincubated for 10 min at $37^{\circ} \mathrm{C}$ or $55^{\circ} \mathrm{C}$ in the denaturing buffer A before addition of RNase T1 and limited hydrolysis for $10 \mathrm{~min}$ at $37^{\circ} \mathrm{C}$; lanes "Con. native" and "Con. denat.": P RNA preincubated for 10 min at $55^{\circ} \mathrm{C}$ in buffer $\mathrm{B}$ or buffer $\mathrm{A}$, respectively, followed by incubation $10 \mathrm{~min}$ at $37^{\circ} \mathrm{C}$ without RNase T1. Cleavage fragments generated by iodine hydrolysis (lanes $A$ and $U$ ) are assigned at the left $(A)$ and right $(C)$ margins according to the $T$. thermophilus $P$ RNA numbering system shown in Figure $1 C$; note that shorter fragments of $A$ and $U$ ladders in panel $C$ show double bands, which we attribute to end heterogeneity of the $3^{\prime}$-endlabeled P RNA. In A and $C$, regions of $T$. thermophilus P RNA that showed reduced or enhanced RNase T1 accessibility after preincubation at $55^{\circ} \mathrm{C}$ versus $37^{\circ} \mathrm{C}$ are marked by gray lettering as well as open and filled circles, respectively, or gray vertical lines; in $C$, structural elements are given in parentheses on the left, below the indicated G residues; J17/16: junction between P17 and P16. Differences in the RNase T1 protection pattern between $T$. thermophilus wt and $\mathrm{mL} 9 \mathrm{P}$ RNA are marked by vertical gray-dotted lines in $B$. The following regions became protected from RNase T1 cleavage upon preincubation of $5^{\prime}$-endlabeled Tth P RNA at $55^{\circ} \mathrm{C}$ versus $37^{\circ} \mathrm{C}$ (A): P11 (3'-strand, G226/227), L13 (G192), J11/12 (G127/129/132/134), P10 (114/5, weakly), P9 (G101-104), P6-8 (G74-76; G79-81; G87/88/93), P4 (G60), J3/4 (G55/56), and the 3'-side of P3 (G49/50/51/53). 3'-endlabeled Tth P RNA (C) provided partially overlapping information, such as protection at G226/7 or signal enhancement (filled dots) at $\mathrm{G} 252 / 3$ upon preincubation at $55^{\circ} \mathrm{C}$; signal intensities were also increased for cleavages in the 3'-part of L15 (G291-3) and in J17/16 (G281/3). 
TABLE 1. Summary of kinetic data of RNA-alone activity assays at $37^{\circ} \mathrm{C}$

\begin{tabular}{|c|c|c|c|c|}
\hline & $K_{\mathrm{m}(\mathrm{sto})}(\mu \mathrm{M})$ & $k_{\text {react }}\left(\min ^{-1}\right)$ & $k_{\text {react }} / K_{\mathrm{m} \text { (sto) }}\left(\mathrm{min}^{-1} \mu \mathrm{M}^{-1}\right)$ & $k_{\text {react }} / K_{\mathrm{M}}(\mathrm{WT}): k_{\text {react }} / K_{\mathrm{M}}$ (mut) \\
\hline Eco WT & $0.65( \pm 0.02)$ & $14.2( \pm 0.1)$ & $\sim 22$ & - \\
\hline Eco mL9 & $0.33( \pm 0.08)$ & $11.1( \pm 0.8)$ & $\sim 34$ & $\sim 0.65$ \\
\hline Tth WT & $0.5( \pm 0.1)$ & $5.3( \pm 0.3)$ & $\sim 11$ & - \\
\hline Tth $\mathrm{mL} 8$ & $0.4( \pm 0.1)$ & $3.1( \pm 0.1)$ & $\sim 8$ & $\sim 1.4$ \\
\hline Tth $\mathrm{mL} 18$ & $1.8( \pm 0.4)$ & $3.6( \pm 0.4)$ & $\sim 2$ & $\sim 5.5$ \\
\hline Tth $\mathrm{mL} 8 / \mathrm{L} 18$ & $1.9( \pm 0.1)$ & $1.0( \pm 0.0)$ & $\sim 0.5$ & $\sim 22$ \\
\hline Tth $\mathrm{mL9}$ & $0.9( \pm 0.2)$ & $6.2( \pm 0.5)$ & $\sim 7$ & $\sim 1.6$ \\
\hline PtrWT & $0.4( \pm 0.1)$ & $10.5( \pm 0.8)$ & $\sim 26$ & - \\
\hline Ptr mL8 & $34( \pm 4) \times 10^{-2}$ & $23( \pm 1) \times 10^{-2}$ & $\sim 0.7$ & $\sim 37$ \\
\hline Ptr mL18 & $29( \pm 2) \times 10^{-2}$ & $21( \pm 1) \times 10^{-2}$ & $\sim 0.7$ & $\sim 37$ \\
\hline Ptr mL8/L18 & $0.4( \pm 0.1)$ & $2.2( \pm 0.2) \times 10^{-2}$ & $\sim 0.06$ & $\sim 430$ \\
\hline Ptr mL9 & $46( \pm 6) \times 10^{-2}$ & $11.0( \pm 0.5)$ & $\sim 24$ & $\sim 1.1$ \\
\hline Dra WT & $0.8( \pm 0.1)$ & $4.4( \pm 0.3)$ & $\sim 5.5$ & - \\
\hline Dra mP9c & $0.9( \pm 0.2)$ & $0.7( \pm 0.1)$ & $\sim 0.8$ & $\sim 6.9$ \\
\hline Dra mL8 & $7.0( \pm 1.7)$ & $0.4( \pm 0.1)$ & $\sim 0.06$ & $\sim 92$ \\
\hline Dra mL9 & $1.1( \pm 0.2)$ & $4.4( \pm 0.3)$ & $\sim 4$ & $\sim 1.4$ \\
\hline Dra mL18 & $2.0( \pm 0.5)$ & $0.4( \pm 0.0)$ & $\sim 0.2$ & $\sim 28$ \\
\hline Dra mL8/L18 & $16.3( \pm 5.2)$ & $2.8( \pm 0.5) \times 10^{-2}$ & $\sim 2 \times 10^{-3}$ & $\sim 3000$ \\
\hline
\end{tabular}

WT: wild type; $K_{\mathrm{m} \text { (sto) }}$ : single turnover $K_{\mathrm{m}} ; K_{\text {react }}$ single turnover $\mathrm{V}_{\max }$. All quantifications are based on at least three independent experiments; errors are standard errors of the curve fit; assay conditions: $100 \mathrm{mM} \mathrm{Mg}(\mathrm{OAc})_{2}, 100 \mathrm{mM} \mathrm{NH}_{4} \mathrm{OAc}, 0.1 \mathrm{mM}$ EDTA, $50 \mathrm{mM} \mathrm{MES,} \mathrm{pH} \mathrm{6.0,} \mathrm{trace} \mathrm{amounts} \mathrm{(<1} \mathrm{nM)} \mathrm{of} T$. thermophilus pre-tRNA ${ }^{\text {Gly }}$, excess amounts of P RNA (E>>S); preincubations: P RNA, 5 min at $55^{\circ} \mathrm{C}$ and 55 min at $37^{\circ} \mathrm{C}$; substrate: 5 min at $55^{\circ} \mathrm{C}$ and 25 $\min$ at $37^{\circ} \mathrm{C}$. Data for Eco P RNA shown for comparison are taken from Marszalkowski et al. (2008).

C360 bp exchange on the L9-P1 interaction. Single turnover RNA-alone kinetics under our standard conditions (see Table 1) revealed no significant difference between the Ptr mL8/L18 P RNA used in Table 1 (with bp G2: C360) relative to the $P \operatorname{tr} m L 8 / L 18 P$ RNA with the native A2:U360 bp. However, the Ptr mL8/L18/L9 P RNA triple mutant (with bp A2:U360) showed a twofold increase in $K_{\mathrm{m}(\mathrm{sto})}$ and a twofold decrease in $k_{\text {react }}$ (based on $\geq 11$ individual kinetic experiments conducted in parallel for each of the three P RNAs). These findings indicate that the L9-P1 contact can form independently in Ptr P RNA, but its contribution to stabilizing the active fold at $37^{\circ} \mathrm{C}$ is minor.

We further analyzed activity of the Dra $\mathrm{mL} 9$ and $\mathrm{mP9c}$ mutant P RNAs. The Dra mL9 mutant P RNA showed a minor (1.4-fold) reduction of catalytic efficiency in RNA-alone assays performed at $37^{\circ} \mathrm{C}$ (Table 1). Likewise, holoenzymes assembled from the Dra mL9 P RNA showed essentially no difference compared with holoenzymes containing the WT P RNA when assayed at $4.5 \mathrm{mM} \mathrm{Mg}^{2+}$, and only moderately reduced cleavage rates at $2 \mathrm{mM} \mathrm{Mg}^{2+}(1.5$-fold with $E$. coli RnpA and $\sim 6.7$-fold with $B$. subtilis RnpA; Table 2). This suggests that the L9-P1 contact forms in this P RNA but makes only a minor contribution to interdomain orientation, as observed for Ptr P RNA. In contrast, much more severe defects were observed for the Dra mP9c mutant RNA particularly in holoenzyme reactions performed at 2 or $4.5 \mathrm{mM} \mathrm{Mg}^{2+}$ (activity losses of three to four orders of magnitude; Table 2).

\section{In vivo complementation analysis}

The WT and mutant P RNAs were tested for their capacity to rescue the lethal phenotype of the Eco P RNA ( $r n p B)$ mutant strain BW (Wegscheid and Hartmann 2006). Among the heterologous rnpB genes, only that of Ptr was able to rescue growth of the mutant strain when provided on a low copy plasmid (Table 3). The failure of Tth rnpB genes (Marszalkowski et al. 2008) to functionally replace Eco rnpB can be explained by the fact that this RNA of thermophilic origin requires temperatures $>>37^{\circ} \mathrm{C}$ (e.g., $55^{\circ} \mathrm{C}$ ) for efficient folding (see above), suggesting insufficient folding in the $\mathrm{E}$. coli host cultivated at $37^{\circ} \mathrm{C}$ or $43^{\circ} \mathrm{C}$. For Dra P RNA, the failure may be related to its unique



FIGURE 7. Schematic model to explain the changes in the P RNA melting profiles upon elimination of the L18-P8 and L8-P4 tertiary contacts relative to the wild-type (WT) P RNA. 
TABLE 2. Holoenzyme kinetics for $P$. translucida, $T$. thermophilus, and $D$. radiodurans $P$ RNAs and $m L 9$ variants thereof reconstituted with the $E$. coli or $B$. subtilis $P$ protein

\begin{tabular}{|c|c|c|}
\hline$P$ (RNA) & $k_{\text {obs }}\left(\min ^{-1}\right)$ E. coli P protein & $k_{\text {obs }}\left(\min ^{-1}\right)$ B. subtilis $\mathrm{P}$ protein \\
\hline Eco WT $2 \mathrm{mM} \mathrm{Mg}^{2+}$ & $3.8( \pm 0.4)$ & $3.0( \pm 0.3)$ \\
\hline Eco WT $4.5 \mathrm{mM} \mathrm{Mg}^{2+}$ & $3.8( \pm 0.4)$ & $4.0( \pm 0.3)$ \\
\hline Ptr WT $2 \mathrm{mM} \mathrm{Mg}^{2+}$ & $3.2( \pm 0.1)$ & $4.2( \pm 0.04)$ \\
\hline Ptr WT $4.5 \mathrm{mM} \mathrm{Mg}^{2+}$ & $3.1( \pm 0.2)$ & $3.0( \pm 0.2)$ \\
\hline Ptr mL9 $2 \mathrm{mM} \mathrm{Mg}^{2+}$ & $3.6( \pm 0.5)$ & $4.7( \pm 0.1)$ \\
\hline Ptr mL9 $4.5 \mathrm{mM} \mathrm{Mg}^{2+}$ & $3.8( \pm 0.5)$ & $3.8( \pm 0.1)$ \\
\hline$k_{\mathrm{obs}} \mathrm{WT} / k_{\mathrm{obs}} \mathrm{mL9}$ & $\begin{array}{l}\sim 0.9\left(2 \mathrm{mM} \mathrm{Mg}^{2+}\right) \\
\sim 0.8\left(4.5 \mathrm{mM} \mathrm{Mg}^{2+}\right)\end{array}$ & $\begin{array}{l}\sim 0.9\left(2 \mathrm{mM} \mathrm{Mg}^{2+}\right) \\
\sim 0.8\left(4.5 \mathrm{mM} \mathrm{Mg}^{2+}\right)\end{array}$ \\
\hline Tth WT $2 \mathrm{mM} \mathrm{Mg}^{2+}$ & $1.3( \pm 0.2)$ & $1.1( \pm 0.1)$ \\
\hline Tth WT $4.5 \mathrm{mM} \mathrm{Mg}^{2+}$ & $4.0( \pm 0.4)$ & $3.5( \pm 0.4)$ \\
\hline Tth $\mathrm{mL} 22 \mathrm{mM} \mathrm{Mg}^{2+}$ & $5.4( \pm 0.8) \times 10^{-2}$ & $0.28( \pm 0.03)$ \\
\hline Tth $\mathrm{mL9} 4.5 \mathrm{mM} \mathrm{Mg}^{2+}$ & $0.2( \pm 0.02)$ & $0.55( \pm 0.02)$ \\
\hline$k_{\mathrm{obs}} \mathrm{WT} / \mathrm{k}_{\mathrm{obs}} \mathrm{mL} 9$ & $\begin{array}{l}24.1\left(2 \mathrm{mM} \mathrm{Mg}^{2+}\right) \\
20\left(4.5 \mathrm{mM} \mathrm{Mg}^{2+}\right)\end{array}$ & $\begin{array}{l}3.9\left(2 \mathrm{mM} \mathrm{Mg}^{2+}\right) \\
6.4\left(4.5 \mathrm{mM} \mathrm{Mg}^{2+}\right)\end{array}$ \\
\hline Dra WT 2 mM Mg${ }^{2+}$ & $1.8( \pm 0.6)$ & $4.0( \pm 1.2)$ \\
\hline Dra WT $4.5 \mathrm{mM} \mathrm{Mg}^{2+}$ & $8.7( \pm 2.3)$ & $6.7( \pm 2.9)$ \\
\hline Dra mL9 $2 \mathrm{mM} \mathrm{Mg}^{2+}$ & $1.2( \pm 0.1)$ & $0.6( \pm 0.2)$ \\
\hline Dra mL9 $4.5 \mathrm{mM} \mathrm{Mg}^{2+}$ & $7.4( \pm 3.1)$ & $7.0( \pm 1.9)$ \\
\hline Dra mP9c $2 \mathrm{mM} \mathrm{Mg}^{2+}$ & $\leq 10^{-4} \mathrm{~min}^{-1}$ & $\leq 5 \times 10^{-4} \min ^{-1}$ \\
\hline Dra mP9c $4.5 \mathrm{mM} \mathrm{Mg}^{2+}$ & $(1.7 \pm 0.3) \times 10^{-3} \mathrm{~min}^{-1}$ & $\leq 4 \times 10^{-3} \min ^{-1}$ \\
\hline$k_{\text {obs }} \mathrm{WT} / k_{\mathrm{obs}} \mathrm{mL} 9$ & $\begin{array}{l}1.5\left(\text { for } 2 \mathrm{mM} \mathrm{Mg}^{2+} \text { ) }\right. \\
1.2\left(\text { for } 4.5 \mathrm{mM} \mathrm{Mg}^{2+} \text { ) }\right.\end{array}$ & $\begin{array}{l}6.4 \text { (for } 2 \mathrm{mM} \mathrm{Mg}^{2+} \text { ) } \\
\sim 1\left(\text { for } 4.5 \mathrm{mM} \mathrm{Mg}^{2+} \text { ) }\right.\end{array}$ \\
\hline$k_{\text {obs }} \mathrm{WT} / k_{\text {obs }} \mathrm{mP9c}$ & $\begin{array}{l}\geq 17600 \text { (for } 2 \mathrm{mM} \mathrm{Mg}^{2+} \text { ) } \\
5135 \text { (for } 4.5 \mathrm{mM} \mathrm{Mg}^{2+} \text { ) }\end{array}$ & $\begin{array}{l}\geq 7900 \text { (for } 2 \mathrm{mM} \mathrm{Mg}^{2+} \text { ) } \\
1680 \text { (for } 4.5 \mathrm{mM} \mathrm{Mg}^{2+} \text { ) }\end{array}$ \\
\hline
\end{tabular}

Reactions were performed as multiple turnover kinetics with recombinant $\mathrm{P}$ protein at $37^{\circ} \mathrm{C}$ in buffer $\mathrm{KN}$ containing $20 \mathrm{mM} \mathrm{Hepes,} 150 \mathrm{mM} \mathrm{NH}{ }_{4} \mathrm{OAc}, 2 \mathrm{mM}$ spermidine, $0.05 \mathrm{mM}$ spermine, $4 \mathrm{mM} \beta$-mercaptoethanol, $\mathrm{pH} 7.4$ at $37^{\circ} \mathrm{C}$, and 2 or $4.5 \mathrm{mM} \mathrm{Mg}(\mathrm{OAc})_{2}$ as indicated, at concentrations of $10 \mathrm{nM}$ P RNA, 100 nM pre-tRNA ${ }^{\text {Gly }}$ substrate and $40 \mathrm{nM} P$ protein; $k_{\mathrm{obs}}$ is given as nmoles substrate converted per nmole of RNase P RNA per min. The data for Eco and Tth $\mathrm{P}$ RNA shown for comparison are taken from Marszalkowski et al. (2008).

architecture in the P9 and P12 regions (Fig. 1), possibly entailing idiosyncratic requirements for the folding process in vivo. This might also be related to expression of a noncanonical $P$ protein in $D$. radiodurans that is predicted to carry a carboxy-terminal extension according to genome annotations. Hence, we could only test the Ptr mutant P RNAs for complementation in strain BW. Whereas the $\mathrm{mL} 8$ and $\mathrm{mL} 8 / \mathrm{L} 18$ variants were nonfunctional, a partial rescue of the growth phenotype was seen for the $\mathrm{mL} 18$ variant (Table 3). This suggests that, in vivo, the L8-P4 contact is more crucial for P RNA function than the L18-P8 interaction, which is consistent with its presence in both types A and B P RNAs and the observation that the $\mathrm{P} 18$ element has been lost in $\mathrm{P}$ RNAs of some bacterial clades, such as in the Aquificales and the genus Chlorobium (Haas et al. 1994; Marszalkowski et al. 2006).

Full rescue of growth of E. coli strain BW under nonpermissive conditions was observed upon expression of the Ptr mL9 mutant P RNA (Table 3). Remarkably, complementation in E. coli was also successful at $43^{\circ} \mathrm{C}$, thus substantially above the maximum growth temperature $\left(30^{\circ} \mathrm{C}\right)$ of
P. translucida. The finding supports the notion that the L9-P1 interaction is of low relevance for function of Ptr RNase $P$ if the L8-P4 and L18-P8 interactions are in place.

\section{DISCUSSION}

The present UV melting analyses have revealed that formation of the L8-P4 and L18-P8 contacts affect structural transitions in one or both P RNA folding domains. Disabling one of the two tertiary contacts has a destabilizing effect in the context of PtrP RNA, a stabilizing effect on Dra P RNA and a marginal effect on Tth P RNA. Such differential effects on melting profiles of Ptr versus Dra P RNA may be related to some $A, U$-rich, low stability structural elements in the PtrP RNA (such as P8 or P18; Fig. 1A) that are stabilized in the native fold. Yet, these partly opposing effects occurred in a context where one of the major interdomain struts (L8-P4 or L18-P8) is assumed to keep a substantial fraction of molecules in the functional interdomain orientation (see below). However, upon simultaneous disruption of both interdomain contacts ( $\mathrm{mL} 8 / \mathrm{L} 18$ double 
TABLE 3. In vivo complementation screen in $E$. coli $\mathrm{rnpB}$ mutant strain BW

\begin{tabular}{lcc}
\hline rnpB & $37^{\circ} \mathrm{C}$ & $43^{\circ} \mathrm{C}$ \\
\hline Eco WT & ++ & ++ \\
Eco mL9 & ++ & ++ \\
Ptr WT & ++ & ++ \\
Ptr mL8 & - & - \\
Ptr mL18 & + & + \\
Ptr mL8/L18 & - & - \\
Ptr mL9 & ++ & ++ \\
Tth WT & - & - \\
Dra WT & - & - \\
\hline
\end{tabular}

Growth of cells was monitored in the presence of $0.5 \%(\mathrm{w} / \mathrm{v})$ glucose (without arabinose), conditions under which the chromosomal rnpB gene of the E. coli mutant strain BW is not expressed (at $37^{\circ}$ as well as $43^{\circ} \mathrm{C}$ ); cells were transformed with derivatives of the low copy plasmid pACYC177 that contained $r n p B$ genes coding for P RNAs and mutants thereof under control of the native rnpB promoter; (-) no cell growth; $(++)$ growth with equal numbers of colonies on arabinose and glucose plates $(+)$ somewhat decreased complementation efficiency according to number and size of colonies; (WT) wild type.

mutant), interactions between the $\mathrm{C}$ - and $\mathrm{S}$-domains are largely lost. The L9-P1 contact is too weak to compensate for the combined disruption of the L18-P8 and L8-P4 contacts. As a result, a uniform overall effect was observed for all three P RNAs: C- and/or S-domains were stabilized such that melting occurred more concertedly with less unfolding at lower temperatures. The net stabilizing effects seen in the melting profiles of the double mutants may have masked minor destabilizing effects, such as those seen for Ptr P RNA upon disruption of the L18-P8 or L8-P4 contact. Since the folding processes are reversible in denaturation and renaturation UV spectroscopy experiments (Supplemental Fig. S6), we conclude that one domain acts as an unfolding chaperone of the other. When the two domains tightly interact, each domain lowers the inherent stability of the other domain (see model in Fig. 7). This may be due to exchange of interactions from intra- to interdomain contacts, especially, but not solely, at the interaction interface (L18-P8 and L8-P4). More indirect effects are conceivable as well, for example that the tertiary interactions induce deviations in coaxial stackings between helices that are part of helical stacks in P RNA.

In line with the UV melting results, the $\mathrm{mL} 8 / \mathrm{L} 18$ double mutation showed the most severe catalytic defect for all three P RNAs, supporting the above assumption that the fraction of $P$ RNA molecules that adopt a productive interdomain orientation is largely decreased in the absence of the L8-P4 and L18-P8 contacts. This depletes the pool of catalytic RNA molecules that are able to position the pretRNA substrate for concerted recognition of the tRNA D/ $\mathrm{T}$ loop by the S-domain and docking of the cleavage site to the active site in the C-domain. The single $\mathrm{mL} 8$ and
$\mathrm{mL} 18$ mutations caused less severe catalytic defects, in line with smaller changes in the UV melting profiles relative to the $\mathrm{mL} 8 / \mathrm{L} 18$-double mutant. This supports the notion that maintaining one of the two tertiary contacts still allows a substantial fraction of $P$ RNAs to adopt a productive interdomain orientation. The thermostable Tth P RNA showed the lowest activity decreases upon disruption of the L8-P4, L18-P8 or both contacts. One reason could be its strengthened L9-P1 contact (see below) combined with its reduced conformational flexibility at $37^{\circ} \mathrm{C}$, which is well below the growth temperature range of $T$. thermophilus $\left(50^{\circ} \mathrm{C}\right.$ and $\left.85^{\circ} \mathrm{C}\right)$. This may have increased the fraction of mutant $P$ RNAs that adopt an active fold relative to $P$ RNAs of mesophilic or psychrophilic origin.

While we stressed the role of the L18-P8 contact for domain orientation, some previously reported functional and structural consequences of its disruption are noteworthy. For Eco P RNA, deletion of P18 caused a substrate binding $\left(K_{M}\right)$ defect in vitro at $25 \mathrm{mM} \mathrm{Mg}^{2+}$ and $1 \mathrm{M}$ $\mathrm{NH}_{4}^{+}$. This defect could be rescued by increasing the $\mathrm{NH}_{4}^{+}$concentration to $3 \mathrm{M}$ (Haas et al. 1994). Likewise, enzyme activity of Eco P RNA with a mutated L18 loop (5'UUCG) could be largely rescued by elevating the $\mathrm{Mg}^{2+}$ concentration to $190 \mathrm{mM}$ at $100 \mathrm{mM} \mathrm{NH}_{4}^{+}$(Pomeranz Krummel and Altman 1999). This suggested electrostatic repulsion effects between enzyme and substrate RNAs upon disruption of the L18-P8 contact. Kirsebom and coworkers probed Eco WT and mL18 (5'-CUUG) P RNA with $\mathrm{Pb}^{2+}$ ions and RNase T1 (Mao et al. 2018). They observed structural changes in $\mathrm{P} 11$ and at the junction between P14 and $\mathrm{P} 11$ in the S-domain of the $\mathrm{mL} 18$ mutant RNA with disrupted L18-P8 interaction. In addition, there was a change in RNase T1 susceptibility at helix P5 in the C-domain, close to the active site. Generally, higher $\mathrm{Pb}^{2+}$ concentrations were required for the $\mathrm{mL} 18$ versus WT P RNA to induce backbone hydrolysis at high affinity metal ion binding sites (Mao et al. 2018). This can be explained by a more flexible structure of the mutant RNA, resulting in affinity losses at $\mathrm{Mg}^{2+}$ binding sites. Even charge distribution at the substrate cleavage site was found to be affected by disruption of the L18-P8 interaction. This was analyzed with a substrate carrying a protonable $2^{\prime}-\mathrm{NH}_{2}$ group at nucleotide -1 near the canonical cleavage site. The $\mathrm{mL} 18$ mutation caused changes in the fraction of substrate that was cleaved at the canonical cleavage $(-1 /+1)$ site at different $\mathrm{pH}$ values (Mao et al. 2018). The authors proposed that the L18-P8 interaction acts as structural mediator between the substrate ( $T$ stem-loop) binding region in the Sdomain and the active center of the $\mathrm{C}$-domain. The contact supports the binding of structurally and catalytically relevant $\mathrm{Mg}^{2+}$ ions, supports native $\mathrm{P}$ RNA folding particularly in the S-domain and optimizes positioning of chemical groups and catalytic $\mathrm{Mg}^{2+}$ ions during catalysis. Noteworthy, Eco WT and mL18 P RNAs were also analyzed by UV melting in a buffer containing $0.4 \mathrm{M} \mathrm{NH}_{4}^{+}$and $1 \mathrm{mM}$ 
$\mathrm{Mg}^{2+}$ (Pomeranz Krummel and Altman 1999). The $\mathrm{mL} 18$ mutation had a destabilizing effect on Eco P RNA, as we observed for Ptr P RNA (Fig. 2A), underscoring the resemblance of the two bacterial type A RNAs.

Certain thermophilic bacteria, such as $T$. thermophilus, have a 5'-GYAA L9 tetraloop and a P1 receptor site consisting of a G-C bp tandem (Massire et al. 1997, Marszalkowski et al. 2006). Such tandem type I/II G-C:A nucleoside triples, where the consecutive $A$ residues interact with the entire (type I) or half (type II) minor groove of the respective G$\mathrm{Cbp}$, represent the most stable combination for this kind of tertiary contact (Doherty et al. 2001). The L9-P1 interdomain contact was shown to contribute to activity of Tth $P$ RNA at elevated temperatures and physiological $\mathrm{Mg}^{2+}$ concentrations. Its disruption by L9 loop mutation prevented formation of a compact conformer observable in native PAA gels (Marszalkowski et al. 2008). In contrast, L9 mutations in Eco P RNA, where two $A$ residues are predicted to interact with a G-U and A-U bp (Massire et al. 1997), had no or little effect on function in vitro and in vivo (Pomeranz Krummel and Altman 1999; Marszalkowski et al. 2008). Likewise, we demonstrated here that a loss of the L9-P1 contact in Ptr P RNA does not abrogate the ability to replace the native Eco P RNA in vivo. Consistent with this finding, the Dra mL9 P RNA showed only a minor reduction in catalytic efficiency in vitro. By testing the $\mathrm{m} L 9$ mutation in Ptr P RNA in the context of disrupted L18-P8 and L8-P4 contacts, we were able to carve out that the L9-P1 contact can form independently. However, its functional contribution was found to be minor. This supports the notion that contacts L8-P4 and L18-P8 are most important for maintaining the functional interdomain orientation in bacterial $P$ RNAs of type $A$. The enhanced functional role of the L9-P1 contact in thermostable P RNAs with a 5'-GYAA L9 and a tandem $\mathrm{G}-\mathrm{C}$ bp receptor in $\mathrm{P} 1$ may also include contributions from the more rigid structural context of the contact. This includes the G-C bp tandem in P1 and the general stabilization of helices, including P1 and P9, by helix extension and/or deletion of nucleotide bulges (Baird et al. 2006; Marszalkowski et al. 2006). This implies that the L9-P1 contact might form more stably in Ptr P RNA at physiological temperatures of its host bacterium $\left(4^{\circ} \mathrm{C}\right.$ to $30^{\circ} \mathrm{C}$ ) owing to reduced conformational dynamics of the RNA relative to $37^{\circ} \mathrm{C}$.

The disruption of the idiosyncratic P9c pseudoknot contact in Dra P RNA moderately affected catalytic performance (approximately sevenfold) in the RNA-alone reaction at high $\mathrm{Mg}^{2+}$ concentration (100 mM; Table 1). However, the mP9c mutation drastically reduced holoenzyme activity at low $\mathrm{Mg}^{2+}\left(\sim 10^{-3}\right.$-fold at $4.5 \mathrm{mM} \mathrm{Mg}^{2+}$, Table 2). Reducing the $\mathrm{Mg}^{2+}$ concentration from 4.5 to 2 $\mathrm{mM}$ further reduced holoenzyme activity $\left(\leq 10^{-4}\right.$-fold), indicating that P9c pseudoknot formation is particularly crucial in the holoenzyme context at physiological $\mathrm{Mg}^{2+}$ concentrations.
Although the psychrophilic bacterium $P$. translucida grows in the range of $4^{\circ} \mathrm{C}$ to $30^{\circ} \mathrm{C}$, its P RNA can functionally replace Eco $P$ RNA in vivo at temperatures above this temperature range $\left(37^{\circ} \mathrm{C}\right.$ or $43^{\circ} \mathrm{C}$, Table 3$)$; likewise, the Ptr $\mathrm{P}$ protein was fully functional in $B$. subtilis at $37^{\circ} \mathrm{C}$ (Gößringer and Hartmann 2007), showing that Ptr RNase $P$ components are stable at temperatures above the growth temperature limit of the bacterium $\left(30^{\circ} \mathrm{C}\right)$. This may suggest that bacterial P RNA ribozymes require a certain minimum overall stability, that is, a minimum number of $G-C$ base pairs, to fold into their functional architecture without the help of protein cofactors. Examples of more A/U-rich P RNAs are only found in eukaryotic organelles, where these RNAs depend on multiple protein cofactors for folding and activity (Schencking et al. 2020). Nevertheless, the PtrP RNA has a reduced $G, C$ content ( $54 \%$ ) relative to the mesophilic Eco P RNA ( 62\%), suggesting increased structural flexibility of the P RNA as an adaptation to psychrophilic growth, in line with the pronounced changes in UV spectra upon introducing the $\mathrm{mL} 8$ and/or mL18 mutation(s) (Fig. 2A). Indeed, several helical elements in Ptr P RNA show hallmarks of reduced stability/increased flexibility (increases in A-U and non-Watson-Crick base pairs, additional bulges; see P1, P3, P8, P18, P11, P12, P17 in Fig. 1A). In this context, we compared the pre-tRNA processing kinetics at assay temperatures of $37^{\circ} \mathrm{C}$ versus $15^{\circ} \mathrm{C}$ (Supplemental Tables 1, 2). The cleavage rate constant $k_{\text {react }}$ at $15^{\circ} \mathrm{C}$ was indeed the highest for Ptr P RNA (compared with Eco, Dra, and Tth P RNAs) in the RNA-alone reaction (Supplemental Table 1), possibly reflecting an adaptation to activity at low temperatures. However, this should be interpreted with caution, because we only measured the processing reaction itself at $15^{\circ} \mathrm{C}$, while RNA folding and holoenzyme assembly were conducted at $55^{\circ} \mathrm{C} / 37^{\circ} \mathrm{C}$. Thus, these experiments did not address effects of low temperature on P RNA and tRNA folding as well as holoenzyme assembly; furthermore, the assembly of the Ptr holoenzyme was performed with the Eco P protein (Supplemental Table 2).

While $D$. radiodurans $R 1$ optimally grows at $\sim 30^{\circ} \mathrm{C}$, its $P$ RNA has characteristics of a thermostable RNA: its $G+C$ content is $\sim 69 \%(71.4 \%$ in Tth P RNA) and its processing activity peaks at $\sim 50^{\circ} \mathrm{C}$ (that of Tth $\mathrm{P}$ RNA at $\sim 60^{\circ} \mathrm{C}$; measured at $25 \mathrm{mM} \mathrm{MgCl}_{2}$ and $1 \mathrm{M} \mathrm{NH}_{4} \mathrm{Cl}$ ). This might contribute to the versatile resistance of the bacterium to stresses including gamma and UV radiation (Setlow and Boling 1965; Battista 1997; Airo et al. 2004), as backbone breaks in thermostable RNAs are less detrimental to RNA function than in mesophilic RNAs. For example, in vitro activity losses of the thermostable Tth P RNA upon $\mathrm{Pb}^{2+}$-induced fragmentation were less pronounced than for Eco P RNA (Ciesiolka et al. 1994).

The group I self-splicing intron is an example of an RNA that first and rapidly folds into a nucleating core structure (the P4/P6 domain), which then serves as a scaffold for folding of its second domain (Doherty and Doudna 1997). In 
contrast, the two domains of bacterial P RNAs (S- and Cdomain) fold in parallel and complete folding of both domains is kinetically indistinguishable (Pan et al. 1999; Kent et al. 2000). RNAs can be classified as slow and fast folding, strongly depending on temperature and ionic conditions. The nature of the rate-limiting step (from the I to the $\mathrm{N}$ state) for the slow-folding class can be assigned to disruption of nonnative or prematurely formed native structures (folding traps). In contrast, the fast-folding class is thought to solely involve small-scale conformational changes, for example the rearrangement of prebound metal ions (Fang et al. 2002; Sosnick and Pan 2004, and refs. therein). It was shown for the mesophilic $B$. subtilis $P$ RNA that the full-length RNA belongs to the class of slow folding RNAs ( $0.2 \mathrm{~min}^{-1}$; measured at $20 \mathrm{mM}$ Tris, $\mathrm{pH} 8.1,10$ to $20 \mathrm{mM} \mathrm{Mg}^{2+}$ and $37^{\circ} \mathrm{C}$; Pan and Sosnick 1997), whereas its isolated $\mathrm{C}$-domain is a member of the fast-folding class (390 $\mathrm{min}^{-1}$; measured at $37.5^{\circ} \mathrm{C}, 20 \mathrm{mM}$ Tris, $\mathrm{pH} 8.1,10$ $\mathrm{mM} \mathrm{Mg}^{2+}$; Fang et al. 1999). The B. subtilis S-domain folds at a rate of $4.5 \mathrm{~min}^{-1}$ (Sosnick and Pan 2004), suggesting that slow folding of the full-length P RNA involves searches for intra- and interdomain contacts during transition to the native structure. Baird et al. (2006) studied the I-to-N transition of the isolated Tth P RNA S-domain by CD spectroscopy relative to the S-domain of Eco P RNA. The Tth Sdomain folded at a lower $\mathrm{Mg}^{2+}$ concentration with increased $\mathrm{Mg}^{2+}$ cooperativity and increased denaturant-sensitive surface burial relative to the mesophilic S-domain. Increased surface burial is in line with stronger protection of the Tth S-domain from RNase T1 cleavage when changing from the $\mathrm{I}$ to the $\mathrm{N}$ state compared with the Eco Sdomain (Baird et al. 2006). Folding equilibria for the two S-domains were analyzed at $37^{\circ} \mathrm{C}$ in the study by Baird et al. (2006) but using an extended time window for the Tth S-domain (up to $70 \mathrm{~min}$ ) relative to the mesophilic counterpart (up to $9 \mathrm{~min}$ ). This indicates that already the Tth S-domain folds at a slower rate than the Eco S-domain at $37^{\circ} \mathrm{C}$, but its activation energy barrier for the l-to- $\mathrm{N}$ transition is clearly lower than for the Tth full-length $P$ RNA that requires a temperature $>>37^{\circ} \mathrm{C}$ for efficient folding (Fig. 5). The high temperature requirement for Tth $P$ RNA folding and the approximately fourfold acceleration of the folding rate by the presence of $3 \mathrm{M}$ urea (Supplemental Fig. S3) indicate that the major activation barrier along the RNA folding pathway is caused by formation of nonnative structures.

These findings are in line with results from previous folding studies of $E$. coli and $B$. subtilis P RNAs, showing that formation of $\mathrm{P} 6$ and $\mathrm{P} 7$ is among the late events in the folding pathway (Zarrinkar et al. 1996; Kent et al. 2000). Backbone discontinuity between P5 and P7 in a circularly permuted B. subtilis P RNA (with the natural 5'- and 3'ends connected by a loop; termed cp240 RNA) enhanced folding 15 -fold at $37^{\circ} \mathrm{C}$, supporting the idea of a folding trap involving the $\mathrm{P7}$ region (Zarrinkar et al. 1996; Pan et al. 1999). Tth P RNA in silico folding with RNAfold (de- fault parameters; Lorenz et al. 2011) predicts most secondary structural elements (including P5 at the domain interface) except for the pseudoknots P4 and P6. However, an alternative structure in the $\mathrm{S}$-domain close to the domain interface, involving pairings between $5^{\prime}-\mathrm{P} 6 / 3^{\prime}-\mathrm{P} 7$ and $5^{\prime}$ P7/3'-P10/P11, is predicted as well (Supplemental Fig. S7). Such a misfold would be consistent with the reported findings cited above.

Our probing experiments showed compactions in several regions of the Tth S-domain upon preincubation at $55^{\circ} \mathrm{C}$, prominently in 5'-P6 and 5'-P7 at the junction between the two domains, but also in the C-domain in $\mathrm{P} 3, \mathrm{~J} 3 / 4$ and helix P4 near its $U$ bulge in the catalytic core as inferred from changes in RNase T1 accessibility (Fig. 6). Formation of the L8-P4 contact might be a major factor contributing to this structural adjustment of the catalytic core. We further noticed some changes in RNase T1 accessibility in the P15-17 subdomain (approximately nucleotide 250-295; Fig. 6A,C). This may be interpreted as suggesting that this subdomain is reoriented upon formation of P6. In summary, the Tth P RNA belongs to a small group of natural thermostable RNAs with very high $\mathrm{G}, \mathrm{C}$ content, resulting in enhanced stability of its secondary and tertiary structure. The RNA is assumed to fold into its active structure without assistance of protein cofactors. The high G,C content and structural stability of the RNA is associated with higher activation barriers that need to be surmounted for proceeding from intermediate folding states to the native fold or to resolve off-pathway folding traps. Here we showed that an intermediate, likely involving nonnative interactions of sequences at the junction of $\mathrm{C}$ - and $\mathrm{S}$-domain, can only be resolved at temperatures as high as $55^{\circ} \mathrm{C}$. Folding from the intermediate to the native fold resulted in substantial structural compaction and loss of surface accessibilty, in line with the results of the previous study on the isolated Tth S-domain (see above; Baird et al. 2006).

\section{MATERIALS AND METHODS}

\section{UV melting}

UV melting profiles were recorded on a Uvikon XL UV/Vis spectrophotometer coupled to a Peltier thermosystem (Biotek) and an automated cell changer for 10 cells and two references. The temperature controller was ramped at a rate of $0.5^{\circ} \mathrm{C} / \mathrm{min}$ from $10^{\circ} \mathrm{C}$ to $90^{\circ} \mathrm{C}$, and data points were collected every $0.4^{\circ} \mathrm{C}$ as determined by a temperature probe inserted into a cuvette containing the final buffer. Samples were measured in $10 \mathrm{mM}$ sodium cacodylate buffer $\mathrm{pH} 7,0.5 \mathrm{mM}$ EDTA, and $100 \mathrm{mM} \mathrm{NaCl}$ at an RNA concentration of $25 \mathrm{nM}$. For data analysis, a script was written to convert concatenated Uvikon report text files into separate denaturation and annealing segments for each position. These were subsequently subjected to piece-wise linear interpolation and smoothed over a $5^{\circ} \mathrm{C}$ window. From this data, the first derivative of absorbance curves $\left(\mathrm{dA}_{260} / \mathrm{dT}\right.$ vs. T) were calculated and plotted as a function of temperature, using either Kaleidagraph 
4.0 (Synergy Software), or Xmgrace. Xmgrace was also used to fit Gaussian normal distributions to derivative melting profiles. Initial constraints were the number of distributions and the starting $T_{m}$, which were iteratively adapted until convergence was obtained.

\section{Construction of plasmids encoding mutant P RNAs used as transcription templates}

Transcription templates for mutant P RNAs (pUC19 derivatives) were constructed using standard PCR techniques as described in Li et al. (2009) or using the Stratagene Quikchange site-directed mutagenesis protocol; DNA sequences were verified by dideoxy sequencing (e.g., custom service by Eurofins Genomics).

\section{In vitro transcription and labeling of RNA $5^{\prime}$ or $3^{\prime}$ ends}

RNAs were produced by run-off transcription with T7 RNA polymerase and subsequent gel purification as described in Busch et al. (2000). The substrate, Tth pre-tRNA ${ }^{\text {Gly }}$, was transcribed from plasmid pSBpt3' $\mathrm{HH}$ linearized with BamHI (Busch et al. 2000), Eco P RNA from plasmid pJA2' (Vioque et al. 1988) linearized with Fokl; Tth, Dra and PtrWT and mutant P RNAs were transcribed from the respective pUC19 derivative plasmids linearized with Ehel, Bbsl, and Fokl, respectively. 5'-endlabeling of pretRNA ${ }^{\text {Gly }}$ and $5^{\prime}$ as well as $3^{\prime}$-endlabeling of $P$ RNAs were performed as detailed in Heide et al. (1999).

\section{Probing experiments}

\section{Partial hydrolysis of T. thermophilus P RNA by RNase T1}

Limited digestion by RNase T1 was performed by incubation of 3 '- or 5'-endlabeled T. thermophilus P RNA (20,000 Cherenkov $\mathrm{cpm}$, also containing $60 \mathrm{ng} / \mu \mathrm{L}$ A. aeolicus $6 \mathrm{~S}$ RNA as carrier) for 10 min at $37^{\circ} \mathrm{C}$ or $55^{\circ} \mathrm{C}$ in buffer $A(20 \mathrm{mM}$ sodium citrate $/ \mathrm{HCl}$, $0.2 \mathrm{mM}$ EDTA, $7 \mathrm{M}$ urea, $\mathrm{pH}$ 5.0) for denaturing conditions or buffer $\mathrm{B}\left(50 \mathrm{mM}\right.$ Hepes $\mathrm{pH} 7.0,4.5 \mathrm{mM} \mathrm{Mg}(\mathrm{OAc})_{2}, 0.1 \mathrm{M} \mathrm{NH}_{4} \mathrm{OAc}, \mathrm{pH}$ 7.5 at $37^{\circ} \mathrm{C}$ ) for native conditions. Hydrolysis was started by addition of RNase T1 (Thermo Fisher Scientific) to a final concentration of $0.16 \mathrm{U} / \mu \mathrm{L}$ followed by $10 \mathrm{~min}$ incubation at $37^{\circ} \mathrm{C}$ and ethanol precipitation to stop the reaction.

\section{lodine-induced hydrolysis of phosphorothioate analog- modified P RNA}

For generation of $U$ or $A$ ladders, modified T. thermophilus P RNA was used. Incorporation of ATP- $\alpha$ S or UTP- $\alpha$ S nucleotides (to 5\% modification) was achieved by run-off transcription (Busch et al. 2000; Heide et al. 2001) using the T7 Y639F mutant RNA polymerase (Sousa and Padilla 1995). lodine hydrolysis was performed in the presence of $10 \mathrm{mM}$ Tris- $\mathrm{HCl} \mathrm{pH} \mathrm{7.5,60} \mathrm{ng/ \mu L} \mathrm{of} A$. aeolicus 6S RNA as carrier RNA and $0.1 \mathrm{mg} / \mathrm{mL} \mathrm{I}_{2}$ for $20 \mathrm{~min}$ at $37^{\circ} \mathrm{C}$.

\section{Probing gels}

All probing samples were loaded onto 12\% PAA/8 M urea gels (thickness: $0.4 \mathrm{~mm}$; width: $16 \mathrm{~cm}$; length: $40 \mathrm{~cm}$ ); gels were run at 6-10 mA until xylene cyanol had migrated $\sim 36 \mathrm{~cm}$ from the slot.

\section{Complementation analyses in the $E$. coli rnpB complementation strain BW}

In vivo complementation assays were performed in the $E$. coli rnpB mutant strain BW with derivatives of plasmid pACYC177 as previously described (Wegscheid and Hartmann 2006); plasmid-borne P RNA coding sequences to be tested were embedded between the native E. coli rnpB promoter and 3'-precursor/ terminator region using standard PCR techniques.

\section{Preparation of recombinant RNase P proteins}

E. coli and B. subtilis RNase P proteins carrying an amino-terminal His-tag (His-tagged peptide leader: MRGSHHHHHHGS, encoded in plasmid pQE-30 in E. coli JM109) were expressed and purified essentially as described (Rivera-León et al. 1995).

\section{Enzyme kinetics}

For single-turnover RNA-alone reactions (Table 1), trace amounts ( $\leq 1 \mathrm{nM}$ ) of $5^{\prime}-{ }^{32} \mathrm{P}$-endlabeled T. thermophilus pre-tRNA ${ }^{\mathrm{Gly}}$ substrate were preincubated in reaction buffer $C(100 \mathrm{mM} \mathrm{Mg}$ $[\mathrm{OAc}]_{2}, 100 \mathrm{mM} \mathrm{NH}_{4} \mathrm{OAc}, 0.1 \mathrm{mM}$ EDTA, $50 \mathrm{mM}$ MES, pH 6.0 at $37^{\circ} \mathrm{C}$ ) for $5 \mathrm{~min}$ at $55^{\circ} \mathrm{C}$ and $25 \mathrm{~min}$ at $37^{\circ} \mathrm{C}$. P RNAs (varied in the range of 0.1 to $15 \mu \mathrm{M}$ ) were preincubated in the same buffer for $5 \mathrm{~min}$ at $55^{\circ} \mathrm{C}$ and $55 \mathrm{~min}$ at $37^{\circ} \mathrm{C}$. Processing reactions were started by combining enzyme and substrate solutions and assayed at $37^{\circ} \mathrm{C}$.

Multiple turnover reactions catalyzed by Tth $\mathrm{P}$ RNA were performed in buffer $\mathrm{D}\left(20 \mathrm{mM} \mathrm{Mg}[\mathrm{OAc}]_{2}, 100 \mathrm{mM} \mathrm{NH} \mathrm{OAc}_{4}, 50\right.$ mM Hepes, pH 7.0), using 20 nM P RNA and 200 mM pretRNA $^{\text {Gly }}$, if not stated otherwise, with P RNA preincubation conditions specified in the figure legend. For reaction conditions in Supplemental Figures S2, S3, see the respective figure legends.

For cleavage assays with reconstituted RNase $\mathrm{P}$ holoenzymes, buffer KN (20 mM Hepes- $\mathrm{NaOH}, 2 \mathrm{mM}$ or $4.5 \mathrm{mM} \mathrm{Mg}[\mathrm{OAc}]_{2}$, $150 \mathrm{mM} \mathrm{NH}_{4} \mathrm{OAc}, 2 \mathrm{mM}$ spermidine, $0.05 \mathrm{mM}$ spermine, and 4 $\mathrm{mM} \beta$-mercaptoethanol, pH 7.4) (Dinos et al. 2004) was used to closely mimic physiological conditions. In vitro reconstitution of RNase $\mathrm{P}$ holoenzymes was performed as follows: $\mathrm{P}$ RNAs were incubated in buffer $\mathrm{KN}$ for $5 \mathrm{~min}$ at $55^{\circ} \mathrm{C}$ and $50 \mathrm{~min}$ at $37^{\circ} \mathrm{C}$, after which RNase P protein was added, followed by another 5 min at $37^{\circ} \mathrm{C}$ before addition of substrate. Cleavage assays were performed at $37^{\circ} \mathrm{C}$. Aliquots of the cleavage reactions were withdrawn at various time points and analyzed by electrophoresis on $20 \%$ polyacrylamide/8 M urea gels. Data analysis and calculations were performed essentially as previously described (Busch et al. 2000). Briefly, gels were subjected to phosphorimaging and radioactive bands representing substrate and 5 -cleavage product were quantified with the AIDA (raytest) image analysis software. First-order rate constants of cleavage $\left(k_{\text {obs }}\right)$ were calculated by fitting the data to the equation for a single exponential: $f_{\text {cleaved }}=f_{\text {endpoint }} \times\left(1-\mathrm{e}^{-k_{\mathrm{obs}} \times t}\right)$, where $f_{\text {cleaved }}=$ fraction of substrate cleaved, $t=$ time, $f_{\text {endpoint }}=$ maximum cleavable substrate (Grafit version 5.0.13, Erithacus Software). For determination of 
single turnover $V_{\max }\left(k_{\text {react }}\right)$ and $K_{\mathrm{M}}\left[K_{\mathrm{M} \text { (sto) }}\right]$ values, $k_{\text {obs }}$ values measured at five different enzyme concentrations (based on at least three replicate experiments each) were plotted against the enzyme concentration; $k_{\text {react }}$ and $K_{\mathrm{M}(\text { sto) }}$ were obtained by fitting the data to a "Michaelis-Menten-like" enzyme kinetics model: $k_{\text {obs }}=k_{\text {react }} \times[\mathrm{P}$ RNA $] /\left(K_{\mathrm{M}(\text { sto })}+[\mathrm{P}\right.$ RNA $\left.]\right)$. For experimental conditions in Supplemental Figure S4, see figure legend.

\section{SUPPLEMENTAL MATERIAL}

Supplemental material is available for this article.

\section{ACKNOWLEDGMENTS}

This work was supported by the German Research Foundation (DFG), grant HA1672/19-1 to R.K.H.

Received March 2, 2021; accepted June 30, 2021.

\section{REFERENCES}

Airo A, Chan SL, Martinez Z, Platt MO, Trent JD. 2004. Heat shock and cold shock in Deinococcus radiodurans. Cell Biochem Biophys 40: 277-288. doi:10.1385/CBB:40:3:277

Appukuttan D, Rao AS, Apte SK. 2006. Engineering of Deinococcus radiodurans $\mathrm{R} 1$ for bioprecipitation of uranium from dilute nuclear waste. Appl Environm Microbiol 72: 7873-7878. doi:10.1128/ AEM.01362-06

Baird NJ, Srividya N, Krasilnikov AS, Mondragón A, Sosnick TR, Pan T. 2006. Structural basis for altering the stability of homologous RNAs from a mesophilic and a thermophilic bacterium. RNA 12: 598-606. doi:10.1261/rna.2186506

Battista JR. 1997. Against all odds: the survival strategies of Deinococcus radiodurans. Annu Rev Microbiol 51: 203-224. doi:10.1146/annurev.micro.51.1.203

Brown JW. 1999. The ribonuclease P database. Nucleic Acids Res 27: 314. doi:10.1093/nar/27.1.314

Brown JW, Nolan JM, Haas ES, Rubio MA, Major F, Pace NR. 1996. Comparative analysis of ribonuclease P RNA using gene sequences from natural microbial populations reveals tertiary structural elements. Proc Natl Acad Sci 93: 3001-3006. doi:10.1073/pnas.93 .7.3001

Busch S, Kirsebom LA, Notbohm H, Hartmann RK. 2000. Differential

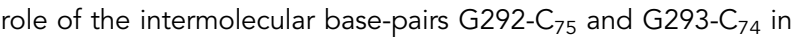
the reaction catalyzed by Escherichia coli RNase P RNA. J Mol Biol 299: 941-951. doi:10.1006/jmbi.2000.3789

Ciesiolka J, Hardt WD, Schlegl J, Erdmann VA, Hartmann RK. 1994. Lead-ion-induced cleavage of RNase P RNA. Eur J Biochem 219: 49-56. doi:10.1111/j.1432-1033.1994.tb19913.x

Corsaro MM, Lanzetta R, Parrilli E, Parrilli M, Tutino ML, Ummarino S. 2004. Influence of growth temperature on lipid and phosphate contents of surface polysaccharides from the antarctic bacterium Pseudoalteromonas haloplanktis TAC 125. J Bacteriol 186: 2934. doi:10.1128/jb.186.1.29-34.2004

Darr SC, Zito K, Smith D, Pace NR. 1992. Contributions of phylogenetically variable structural elements to the function of the ribozyme ribonuclease P. Biochemistry 31: 328-333. doi:10.1021/ bi00117a003

Dinos G, Wilson DN, Teraoka Y, Szaflarski W, Fucini P, Kalpaxis D, Nierhaus KH. 2004. Dissecting the ribosomal inhibition mechanisms of edeine and pactamycin: the universally conserved resi- dues G693 and C795 regulate P-site RNA binding. Mol Cell 13: 113-124. doi:10.1016/s1097-2765(04)00002-4

Doherty EA, Doudna JA. 1997. The P4-P6 domain directs higher order folding of the Tetrahymena ribozyme core. Biochemistry 36: 3159-3169. doi:10.1021/bi962428+

Doherty EA, Batey RT, Masquida B, Doudna JA. 2001. A universal mode of helix packing in RNA. Nat Struct Biol 8: 339-343. doi:10.1038/86221

Fang XW, Pan T, Sosnick TR. 1999. $\mathrm{Mg}^{2+}$-dependent folding of a large ribozyme without kinetic traps. Nat Struct Biol 6: 1091-1095. doi:10.1038/70016

Fang XW, Thiyagarajan P, Sosnick TR, Pan T. 2002. The rate-limiting step in the folding of a large ribozyme without kinetic traps. Proc Natl Acad Sci 99: 8518-8523. doi:10.1073/pnas.142288399

Gösringer M, Hartmann RK. 2007. Function of heterologous and truncated RNase P proteins in Bacillus subtilis. Mol Microbiol 66: 801813. doi:10.1111/j.1365-2958.2007.05962.x

Gößringer M, Kretschmer-Kazemi Far R, Hartmann RK. 2006. Analysis of RNase $P$ protein ( $r n p A$ ) expression in Bacillus subtilis utilizing strains with suppressible rnpA expression. J Bacteriol 188: 68166823. doi:10.1128/JB.00756-06

Gößringer M, Schencking I, Hartmann RK. 2021. The RNase P ribozyme. In Ribozymes: principles, methods, applications (ed. Müller S, et al.), pp. 227-280. Wiley-VCH, Weinheim, Germany.

Guerrier-Takada C, Gardiner K, Marsh T, Pace N, Altman S. 1983. The RNA moiety of ribonuclease $P$ is the catalytic subunit of the enzyme. Cell 35: 849-857. doi:10.1016/0092-8674(83)90117-4

Haas ES, Banta AB, Harris JK, Pace NR, Brown JW. 1996. Structure and evolution of ribonuclease P RNA in Gram-positive bacteria. Nucleic Acids Res 24: 4775-4782. doi:10.1093/nar/24.23.4775

Haas ES, Brown JW. 1998. Evolutionary variation in bacterial RNase P RNAs. Nucleic Acids Res 26: 4093-4099. doi:10.1093/nar/26.18 .4093

Haas ES, Brown JW, Pitulle C, Pace NR. 1994. Further perspective on the catalytic core and secondary structure of ribonuclease P RNA. Proc Natl Acad Sci 91: 2527-2531. doi:10.1073/pnas.91.7.2527

Hartmann RK, Erdmann VA. 1991. Analysis of the gene encoding the RNA subunit of ribonuclease $P$ from $T$. thermophilus HB8. Nucleic Acids Res 19: 5957-5964. doi:10.1093/nar/19.21.5957

Hartmann RK, Gößringer M, Späth B, Fischer S, Marchfelder A. 2009. The making of tRNAs and more: RNase $P$ and tRNase Z. Prog Mol Biol Transl Sci 85: 319-368. doi:10.1016/S0079-6603(08)00808-8

Heide C, Pfeiffer T, Nolan JM, Hartmann RK. 1999. Guanosine 2-NH2 groups of Escherichia coli RNase P RNA involved in intramolecular tertiary contacts and direct interactions with tRNA. RNA 5: 102116. doi:10.1017/s1355838299981499

Heide C, Feltens R, Hartmann RK. 2001. Purine N7 groups that are crucial to the interaction of Escherichia coli RNase P RNA with tRNA. RNA 7: 958-968. doi:10.1017/s1355838201001753

Jarrous N, Gopalan V. 2010. Archaeal/eukaryal RNase P: subunits, functions and RNA diversification. Nucleic Acids Res 38: 78857894. doi:10.1093/nar/gkq701

Kent O, Chaulk SG, MacMillan AM. 2000. Kinetic analysis of the M1 RNA folding pathway. J Mol Biol 304: 699-705. doi:10.1006/ jmbi.2000.4263

Klemm BP, Wun N, Chen Y, Liu X, Kaitany KJ, Howard MJ, Fierke CA. 2016. The diversity of Ribonuclease P: protein and RNA catalysts with analogous biological functions. Biomolecules 13: 6. doi:10 .3390/biom6020027

Lai LB, Tanimoto A, Lai SM, Chen WY, Marathe IA, Westhof E, Wysocki VH, Gopalan V. 2017. A novel double kink-turn module in euryarchaeal RNase P RNAs. Nucleic Acids Res 45: 74327440. doi:10.1093/nar/gkx388

Li D, Willkomm DK, Hartmann RK. 2009. Minor changes largely restore catalytic activity of archaeal RNase P RNA from 
Methanothermobacter thermoautotrophicus. Nucleic Acids Res 37: 231-242. doi:10.1093/nar/gkn915

Lorenz R, Bernhart SH, Hoener zu Siederdissen C, Tafer H, Flamm C, Stadler PF, Hofacker IL. 2011. ViennaRNA Package 2.0. Algorithms Mol Biol 6: 26. doi:10.1186/1748-7188-6-26

Loria A, Pan T. 1996. Domain structure of the ribozyme from eubacterial ribonuclease P. RNA 2: 551-563.

Mao G, Srivastava AS, Wu S, Kosek D, Lindell M, Kirsebom LA. 2018. Critical domain interactions for type A RNase P RNA catalysis with and without the specificity domain. PLoS ONE 13: e0192873. doi: 10.1371/journal.pone.0192873

Marszalkowski M, Teune JH, Steger G, Hartmann RK, Willkomm DK. 2006. Thermostable RNase P RNAs lacking P18 identified in the Aquificales. RNA 12: 1915-1921. doi:10.1261/rna.242806

Marszalkowski M, Willkomm DK, Hartmann RK. 2008. Structural basis of a ribozyme's thermostability: p1-L9 interdomain interaction in RNase P RNA. RNA 14: 127-133. doi:10.1261/rna.762508

Massire C, Jaeger L, Westhof E. 1997. Phylogenetic evidence for a new tertiary interaction in bacterial RNase P RNAs. RNA 3: 553556.

Massire C, Jaeger L, Westhof E. 1998. Derivation of the three-dimensional architecture of bacterial ribonuclease P RNAs from comparative sequence analysis. J Mol Biol 279: 773-793. doi:10.1006/ jmbi.1998.1797

Medigue C, Krin E, Pascal G, Barbe V, Bernsel A, Bertin PN, Cheung F, Cruveiller S, D'Amico S, Duilio A, et al. 2005. Coping with cold: the genome of the versatile marine Antarctica bacterium Pseudoalteromonas haloplanktis TAC125. Genome Res 15: 1325-1335. doi:10.1101/gr.4126905

Oshima T, Imahori K. 1974. Description of Thermus thermophilus (Yoshida and Oshima) comb. nov., a nonsporulating Thermophilic bacterium from a Japanese thermal spa. Int J Systemat Bacteriol 24: 102-112. doi:10.1099/00207713-24-1-102

Pan T, Sosnick T. 1997. Intermediates and kinetic traps in the folding of a large ribozyme revealed by circular dichroism and UV absorbance spectroscopies and catalytic activity. Nat Struct Biol 4: 931-938. doi:10.1038/nsb1197-931

Pan T, Fang X, Sosnick T. 1999. Pathway modulation, circular permutation and rapid RNA folding under kinetic control. J Mol Biol 286: 721-731. doi:10.1006/jmbi.1998.2516

Pomeranz Krummel DA, Altman S. 1999. Verification of phylogenetic predictions in vivo and the importance of the tetraloop motif in a catalytic RNA. Proc Natl Acad Sci 96: 11200-11205. doi:10 .1073/pnas.96.20.11200

Reiter NJ, Osterman A, Torres-Larios A, Swinger KK, Pan T, Mondragón A. 2010. Structure of a bacterial ribonuclease P holo- enzyme in complex with tRNA. Nature 468: 784-789. doi:10 $.1038 /$ nature09516

Rivera-León R, Green CJ, Vold BS. 1995. High-level expression of soluble recombinant RNase $\mathrm{P}$ protein from Escherichia coli. J Bacteriol 177: 2564-2566. doi:10.1128/jb.177.9.2564-2566.1995

Schencking I, Rossmanith W, Hartmann RK. 2020. Diversity and evolution of RNase P. In Evolutionary biology-a transdisciplinary approach (ed. Pontarotti P), pp. 255-299. Springer, Cham. doi:10.1007/978-3-030-57246-4_11

Schlegl J, Hardt WD, Erdmann VA, Hartmann RK. 1994. Contribution of structural elements to Thermus thermophilus ribonuclease $P$ RNA function. EMBO J 13: 4863-4869. doi:10.1002/j.1460-2075 .1994.tb06813.x

Setlow JK, Boling ME. 1965. The resistance of Micrococcus radiodurans to ultraviolet radiation. II. Action spectra for killing, delay in DNA synthesis, and thymine dimerization. Biochim Biophys Acta 108: 259-265. doi:10.1016/0005-2787(65)90010-9

Siegel RW, Banta AB, Haas ES, Brown JW, Pace NR. 1996. Mycoplasma fermentans simplifies our view of the catalytic core of ribonuclease P RNA. RNA 2: 452-462.

Sosnick TR, Pan T. 2004. Reduced contact order and RNA folding rates. J Mol Biol 342: 1359-1365. doi:10.1016/j.jmb.2004.08.002

Sousa R, Padilla R. 1995. A mutant T7 RNA polymerase as a DNA polymerase. EMBO J 14: 4609-4621. doi:10.1002/j.1460-2075.1995 .tb00140.x

Torres-Larios A, Swinger KK, Krasilnikov AS, Pan T, Mondragón A. 2005. Crystal structure of the RNA component of bacterial ribonuclease P. Nature 437: 584-587. doi:10.1038/nature04074

Vioque A, Arnez J, Altman S. 1988. Protein-RNA interactions in the RNase P holoenzyme from Escherichia coli. J Mol Biol 202: 835848. doi:10.1016/0022-2836(88)90562-1

Wan F, Wang Q, Tan J, Tan M, Chen J, Shi S, Lan P, Wu J, Lei M. 2019. Cryo-electron microscopy structure of an archaeal ribonuclease $P$ holoenzyme. Nat Commun 10: 2617. doi:10.1038/s41467-01910496-3

Waugh DS, Pace NR. 1990. Complementation of an RNase P RNA $(\mathrm{rnp} B)$ gene deletion in Escherichia coli by homologous genes from distantly related eubacteria. J Bacteriol 172: 6316-6322. doi:10.1128/jb.172.11.6316-6322.1990

Waugh DS, Green CJ, Pace NR. 1989. The design and catalytic properties of a simplified ribonuclease P RNA. Science 244: 15691571. doi:10.1126/science. 2472671

Wegscheid B, Hartmann RK. 2006. The precursor tRNA 3'-CCA interaction with Escherichia coli RNase P RNA is essential for catalysis by RNase $\mathrm{P}$ in vivo. RNA 12: 2135-2148. doi:10.1261/rna.188306

Zarrinkar PP, Wang J, Williamson JR. 1996. Slow folding kinetics of RNase P RNA. RNA 2: 564-573. 

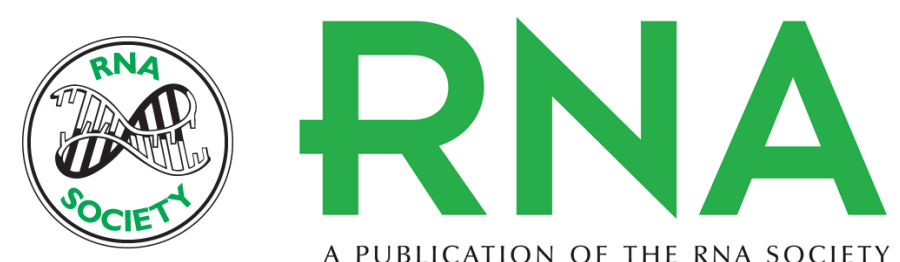

A PUBLICATION OF THE RNA SOCIETY

\section{Comparative study on tertiary contacts and folding of RNase P RNAs from a psychrophilic, a mesophilic/radiation-resistant, and a thermophilic bacterium}

Michal Marszalkowski, Andreas Werner, Ralph Feltens, et al.

RNA 2021 27: 1204-1219 originally published online July 15, 2021

Access the most recent version at doi:10.1261/rna.078735.121

Supplemental Material

References

Open Access

Creative Commons License

Email Alerting Service
http://rnajournal.cshlp.org/content/suppl/2021/07/15/rna.078735.121.DC1

This article cites 57 articles, 20 of which can be accessed free at: http://rnajournal.cshlp.org/content/27/10/1204.full.html\#ref-list-1

Freely available online through the RNA Open Access option.

This article, published in RNA, is available under a Creative Commons License (Attribution-NonCommercial 4.0 International), as described at http://creativecommons.org/licenses/by-nc/4.0/.

Receive free email alerts when new articles cite this article - sign up in the box at the top right corner of the article or click here.

To subscribe to $R N A$ go to:

http://rnajournal.cshlp.org/subscriptions 